\title{
Characterisation and Life Cycle Assessment of Pervious Concrete with Recycled Concrete Aggregates
}

\author{
Adilson C. Paula Junior ${ }^{1, *}$, Cláudia Jacinto ${ }^{1}$, Thaís M. Oliveira ${ }^{2}$, Antonio E. Polisseni ${ }^{2}$, Fabio M. Brum ${ }^{3}$, \\ Elisabete R. Teixeira ${ }^{1}$ (D) and Ricardo Mateus ${ }^{1}$ (D)
}

1 Department of Civil Engineering, Institute for Sustainability and Innovation in Structural Engineering (ISISE) University of Minho, 4800-058 Guimarães, Portugal; pg39217@alunos.uminho.pt (C.J.); b8416@civil.uminho.pt (E.R.T.); ricardomateus@civil.uminho.pt (R.M.)

2 Department of Civil Construction, Faculty of Engineering, Federal University of Juiz de Fora, 36036-900 Juiz de Fora, Brazil; thais.mayra@ufff.edu.br (T.M.O.); polisseni.eduardo2014@engenharia.uff.br (A.E.P.)

3 Infrastructure Office (ProInfra), Federal University of Juiz de Fora, 36036-900 Juiz de Fora, Brazil; fabio.brum@ufjf.br

* Correspondence: id8639@alunos.uminho.pt; Tel.: +351-253-510-200

check for updates

Citation: Paula Junior, A.C.; Jacinto, C.; Oliveira, T.M.; Polisseni, A.E.; Brum, F.M.; Teixeira, E.R.; Mateus, R. Characterisation and Life Cycle Assessment of Pervious Concrete with Recycled Concrete Aggregates. Crystals 2021, 11, 209. https:// doi.org/10.3390/cryst11020209

Academic Editor:

Per-Lennart Larsson

Received: 20 January 2021

Accepted: 18 February 2021

Published: 20 February 2021

Publisher's Note: MDPI stays neutral with regard to jurisdictional claims in published maps and institutional affiliations.

Copyright: (c) 2021 by the authors. Licensee MDPI, Basel, Switzerland. This article is an open access article distributed under the terms and conditions of the Creative Commons Attribution (CC BY) license (https:/ / creativecommons.org/licenses/by/ $4.0 /)$.

\begin{abstract}
The search for environmental preservation and conservation of natural resources gives rise to new concepts and viable technical solutions on the path to sustainable development. In this context, this study's main objective is to analyse the influence of recycled concrete aggregates (RCAs) on the development of pervious concrete, whose use as a floor covering represents an excellent device to mitigate the urban soil sealing phenomena. For this, mechanical and hydraulic tests were carried out, in addition to microstructural analyses and the assessment of its environmental performance. The results obtained were compared to reference studies also involving the incorporation of recycled aggregates. A pilot-scale case study was conducted, involving a parking space lined with pervious concrete moulded "in situ". In laboratory tests, permeability coefficients and mechanical strengths compatible with the literature and above the normative limit for light traffic were found. The case study demonstrated higher permeability than in the laboratory, but the flexural strength was lower, being indicated only for pedestrian traffic. The environmental assessment showed that the RCA represents a positive contribution to the environmental performance of pervious concrete. Still, attention should be given to the recycled aggregate transport distance between the concrete plant and the RCA treatment plant.
\end{abstract}

Keywords: pervious concrete; recycled concrete aggregate; construction and demolition waste; permeability; mechanical properties; environmental assessment; microstructural analyses

\section{Introduction}

Nowadays, sustainability issues and the conservation of mineral deposits promote new concepts and technical solutions aiming to follow a circular economy in their productive system [1]. The increasing production and subsequent disposal of construction and demolition waste (CDW) are currently major environmental and social problems [2]. These material wastes, usually non-degradable, are typically sent to landfills or dumped illegally, raising questions about waste management $[3,4]$. In the European Union, the annual production of construction waste is around 900 million tonnes, contributing to $25 \%$ to $30 \%$ of all waste produced [5-7]. The recycling and reuse of CDW in the form of recycled concrete aggregates (RCAs) is a sustainable alternative and has great potential to reduce the volume of landfill disposal, the extraction of natural resources, and the associated pollution from raw materials' treatment [3,8-11].

Some studies demonstrate that the use of recycled aggregates is often associated with the loss of physical and mechanical properties of concrete [12-14]. This is due to the 
lower density and higher porosity and water absorption of RCAs $[15,16]$. Several authors correlate these characteristics with the inferior properties of the interfacial transition zone between the recycled aggregate and the cement paste, which leads to a loss of adhesion between the phases $[4,17,18]$. However, given the current rainwater management problems faced by urban drainage systems, pervious concrete offers several environmental benefits, including rainwater run-off control, groundwater replenishment, improvement of water quality, and decreased need for holding tanks and other expensive rainwater collection systems [3,10,19-21]. Additionally, pervious concrete also contributes to sound absorption, regulation of heat and humidity, and increased skid resistance, as it prevents water from remaining on the pavement surface [2,22-24].

Pervious concrete commonly presents a void index of $15 \%$ to $35 \%$, with permeability between 0.2 and $1.2 \mathrm{~cm} / \mathrm{s}$. Its density varies between 1600 and $2000 \mathrm{~kg} / \mathrm{m}^{3}$ and its flexural strength is between 1 and 3.8 MPa $[10,25,26]$. However, due to the high void index, the compressive strength of pervious concrete is less than that of conventional concrete and varies between 2.8 and $28 \mathrm{MPa}[2,4,27,28]$. Thus, pervious concrete can only be applied in situations with fewer mechanical requirements, such as sidewalks, parking lots, stone protection, drainage paving, prefabricated products, and rainwater retention facilities, among others $[3,8,21]$.

In this study, the main objective is to prepare an RCA-based pervious concrete, minimising production costs and maximising the environmental performance within the technical parameters observed in the literature and respecting the normative requirements. It is essential to analyse and compare the potential environmental impacts related to the production of pervious concrete, and the impacts arising from RCAs or natural aggregates. One of the best approaches to develop this type of study is to use the Life Cycle Analysis (LCA) method $[29,30]$. This method allows quantifying the potential environmental impacts of products or services. It quantifies both inflows (e.g., energy, water, and materials) and outflows (e.g., $\mathrm{CO}_{2}$ emissions, solid waste, and liquid waste) to and from the system under analysis [31,32]. Based on the context and methodological approach mentioned, this study quantified the functional properties and potential environmental impacts of producing RCA-based pervious concrete by comparing it to conventional concrete with similar cement content, made available by a local concrete company.

Pervious concrete represents a favourable scope in the search to reduce urban surface waterproofing through eco-friendly and economically viable methods. However, the great challenge in developing this material is the difficulty of achieving the proper balance between its mechanical and hydraulic properties [33]. In this context, the present work aims to analyse the environmental and functional characteristics of pervious concrete with RCAs and natural aggregates to explore solutions further to improve the sustainability of the final product.

\section{Materials and Methods}

\subsection{Raw Materials}

Portland cement CP V-ARI was used in the production of the RCA-based pervious concrete. Similar to American Society for Testing and Materials (ASTM) Type III cement, it follows the specifications of Brazilian standard (Norma Brasileira) NBR 16697 [34]. This binder was chosen because it belongs to a cement class that has a higher percentage of clinker in its composition. Its unique proportion of limestone and clay, combined with a more intense grinding process, allows the cement to achieve higher strengths in shorter periods when reacting with water [35]. This shorter setting time is also important because pervious concrete, due to its high surface area exposed to the air, tends to lose water from the mixture more quickly. Its high reactivity in the first hours also helps to reduce the pores filling during the conglomerate formation.

As the conventional concrete (reference), Portland cement type CP III 40 RS was used according to the recommendations of NBR 16697 [34]. This designation refers to a hydraulic binder obtained by the homogeneous mixture of clinker and blast furnace slag, with low 
hydration heat, stable in the presence of reactive aggregates and resistant to sulphates. This type of cement was chosen because it is one of the most used in the study region. The physical and chemical compositions of the cement types used in this research are presented in Table 1.

Table 1. Chemical composition, physical properties, and mechanical performance of the types of cements used.

\begin{tabular}{ccc}
\hline Component & Cement CP V-ARI & Cement CP III 40 RS \\
\hline $\mathrm{MgO}(\%)$ & 1.4 & 3.49 \\
$\mathrm{SO}_{3}(\%)$ & 3.2 & 1.63 \\
$\mathrm{Na}_{2} \mathrm{O}(\%)$ & 0.07 & - \\
$\mathrm{K}_{2} \mathrm{O}(\%)$ & 0.89 & 0.70 \\
$\mathrm{Na}_{2} \mathrm{O}_{\text {eq }}(\%)$ & 0.65 & - \\
Properties & 1.4 & 1.14 \\
Insoluble Residue (IR) $(\%)$ & & \\
Blaine (cm $\left.{ }^{2} / \mathrm{g}\right)$ & 4617 & 4630 \\
Initial Set (min) & 157 & 200 \\
Final Set (min) & 212 & - \\
Compressive Strength & & \\
1 Day (MPa) & 30 & 12.7 \\
3 Days (MPa) & 41.7 & 25.4 \\
7 Days (MPa) & 46.4 & 34.9 \\
28 Days (MPa) & 55.4 & 47.8 \\
\hline
\end{tabular}

Coarse aggregates are responsible for forming a resistant and stable mineral skeleton in paving concretes. In this work, all the coarse aggregates used in the pervious concrete composition consisted of concrete waste selected from CDW (Figure 1). This material was extracted from different types of construction and demolition works carried out on the Federal University of Juiz de Fora (UFJF), having no specific origin or strength class. However, only concretes that initially had a structural function were used as RCAs, without having any physical or chemical treatment to remove the adhered mortar. Currently, Brazilian standards limit the use of recycled aggregates to pavement sublayers and concretes with no structural function.

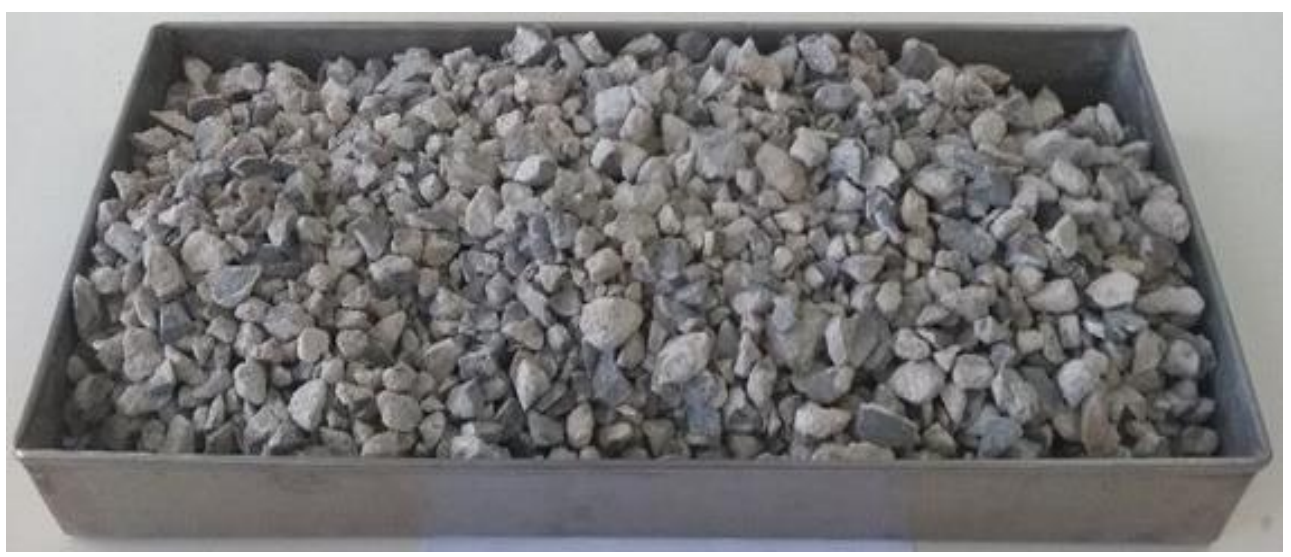

Figure 1. Crushed concrete waste.

The CDW was crushed with the aid of a jaw crusher, followed by granulometric separation using an automatic vibrating sieve. For this research, only the particle size range between 9.5 and $25 \mathrm{~mm}$ was used. However, as the aggregate is a CDW, its particles' sizes tend to vary, since the materials disintegrate more easily. It is important to note that three RCA samples were characterised to guarantee the quality and representativeness of the results. Table 2 presents the average of the results. 
The conventional concrete, on the other hand, consisted of two types of fine aggregate, natural sand (NS) and artificial sand (AS), and two gravel grades, both of natural origin, G0 and G1 (4.75 to $12.5 \mathrm{~mm}$ and 9.5 to $25 \mathrm{~mm}$, respectively). All these materials were sourced nearby. Figure 2 shows the particle size distribution of the aggregates used in the study, following the methodology recommended by NBR NM 248 [36]. Table 2 presents their physical properties, according to the respective Brazilian standards.

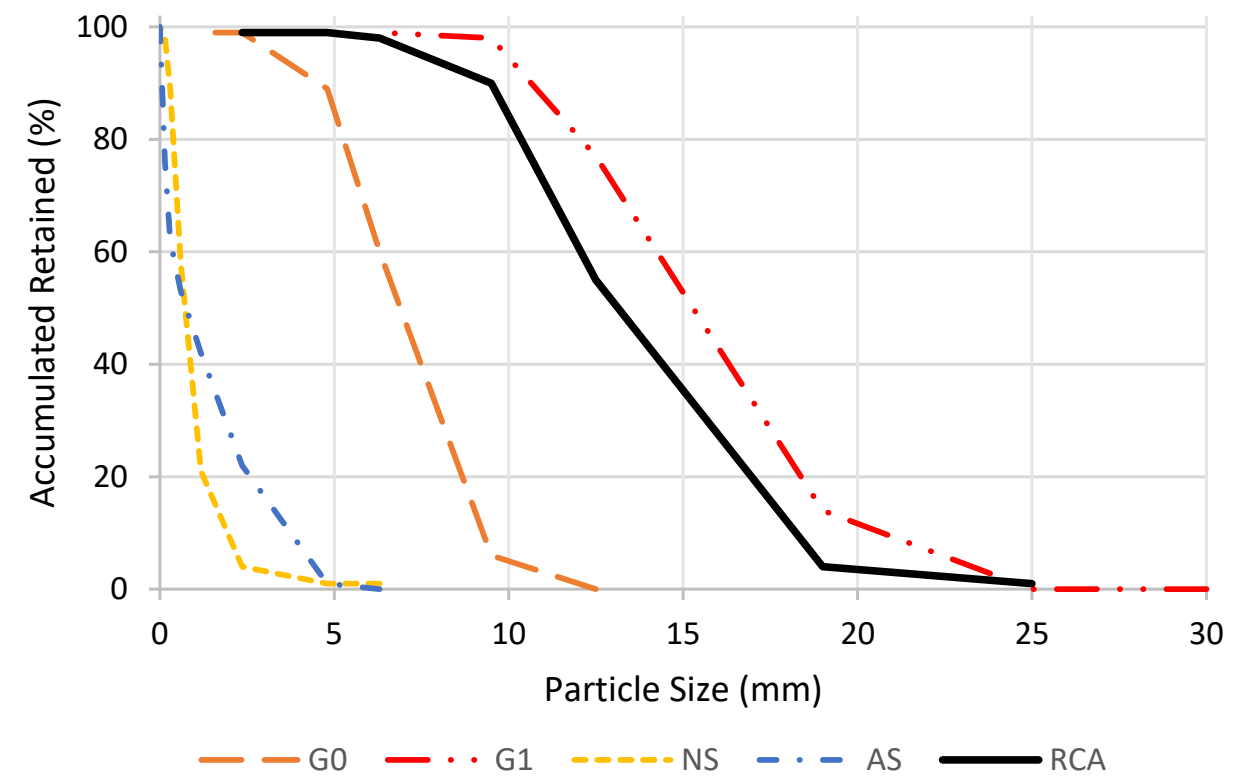

Figure 2. Particle size distribution of the aggregates.

Table 2. Physical properties of the aggregates.

\begin{tabular}{ccccccc}
\hline Properties & Standard & RCA & G0 & G1 & NS & AS \\
\hline Volumic Mass $\left(\mathrm{cm}^{3} / \mathrm{g}\right)$ & NBR NM 53 [37] & 2.68 & 2.76 & 2.85 & 2.60 & 2.73 \\
Density $\left(\mathrm{g} / \mathrm{cm}^{3}\right)$ & NBR NM 45 [38] & 1.31 & 1.40 & 1.49 & 1.44 & 1.72 \\
Pulverulent Materials Content (\%) & NBR NM 46 [39] & 0.6 & 0.685 & 0.945 & 2.25 & 20.8 \\
Water Absorption (\%) & NBR NM 53 [37] & 3.8 & - & - & - & - \\
Abrasion Los Angeles (\%) & NBR NM 51 [40] & 48.5 & - & - & - & - \\
\hline
\end{tabular}

For the conventional concrete, a polyfunctional plasticiser additive was used. With a density of $1.18 \pm 0.02 \mathrm{~g} / \mathrm{cm}^{3}$, it was formulated for use in cement types with a high content of additions without hindering the initial resistance or delaying the start of setting time, even at low temperatures and with an increase in the final resistances. As for the pervious concrete, no additives were used. In the same way, no RCA treatment was used to reduce the negative environmental impact further. Moreover, studies carried out by [41] demonstrated that the plasticiser is not necessary for designing this type of concrete.

\subsection{Mixture Proportions and Procedures}

The pervious concrete was prepared according to the American Concrete Institute standard ACI 522R-10 [27]. This standard clarifies that the cement/aggregate ratio and the compaction procedure used in the production of pervious concretes are factors of fundamental importance to the mixture since they directly influence the mechanical characteristics of the material. In this sense, a manual concrete compaction method was adopted to reproduce the expected density in the field [42]. As suggested by Yap et al. [3], special compaction methods were not employed due to increased energy consumption. This was also to avoid segregation of the particles and excessive densification of the cement paste, which would decrease the drainage capacity of the concrete samples. 
The density of the pervious concrete was established at $1600 \mathrm{~kg} / \mathrm{m}^{3}$, which is the minimum design limit according to ACI 522R [27]. A value of 0.35 was adopted for the water/cement factor $(\mathrm{w} / \mathrm{c})$, considering the expected high water absorption content of the RCA used in the concrete production. Higher w/c ratios are associated with better formation of hydrated products, improving cohesion between aggregates and the development of higher mechanical strength [43], without affecting the hydraulic properties of the concrete [28]. Table 3 presents the mixtures of the pervious concrete and the conventional concrete developed by a local concrete company, used as a reference.

Table 3. Mixture proportions of studied concretes.

\begin{tabular}{|c|c|c|c|c|c|c|c|c|}
\hline $\begin{array}{l}\text { Mix Desig- } \\
\text { nation }\end{array}$ & $\begin{array}{l}\text { Cement } \\
\left(\mathrm{kg} / \mathrm{m}^{3}\right)\end{array}$ & $\begin{array}{c}\text { RCA } \\
\left(\mathrm{kg} / \mathrm{m}^{3}\right)\end{array}$ & $\begin{array}{c}\mathrm{G} 0 \\
\left(\mathrm{~kg} / \mathrm{m}^{3}\right)\end{array}$ & $\begin{array}{c}\mathrm{G} 1 \\
\left(\mathrm{~kg} / \mathrm{m}^{3}\right)\end{array}$ & $\begin{array}{c}\mathrm{NS} \\
\left(\mathrm{kg} / \mathrm{m}^{3}\right)\end{array}$ & $\underset{\left(\mathrm{kg} / \mathrm{m}^{3}\right)}{\mathrm{AS}}$ & $\begin{array}{l}\text { Water } \\
\left(\mathrm{kg} / \mathrm{m}^{3}\right)\end{array}$ & $\begin{array}{c}\text { Additive } \\
\left(\mathrm{kg} / \mathrm{m}^{3}\right)\end{array}$ \\
\hline PC-R100 & 312 & 1179 & - & - & - & - & 109 & - \\
\hline CC-Ref-R0 & 320 & - & 311 & 725 & 672 & 224 & 176 & 2.08 \\
\hline
\end{tabular}

For the mixing procedures, the methodology recommended by Schaefer et al. [44] was followed, adapting it to the incorporation of RCA based on recent studies on the subject $[2-4,7,10,13]$. According to the reference literature, this methodology allows for optimising the hydraulic and mechanical properties of pervious concrete.

The recycled aggregates were pre-humidified until close to the saturated surface dry (SSD) condition to avoid water absorption during the concrete mixing process. This material was mixed with cement in a previously lubricated rotating concrete mixer with cement paste removed from the mix. Water was then added gradually to the mixture to ensure homogeneity. After $3 \mathrm{~min}$, the mixer was turned off for $2 \mathrm{~min}$ for the ball-inhand consistency test, according to the international standard ASTM C 860-15 [45]. Since pervious concrete does not produce significant abatement, this test was conducted to verify that the fresh mixture was sufficiently moistened to form an appropriate aggregate-paste bond $[3,10]$. The concrete was further mixed for $2 \mathrm{~min}$, followed by the fresh density test, according to NBR 9833 [46]. Finally, the fresh concrete was poured into the sample moulds in two layers, compacted manually with the aid of metal sticks, and finished with a trowel.

All compacted specimens were subsequently covered with damp cloths and kept at constant saturation to prevent evaporation of the water in the mixture. Due to pervious concrete's structure, exuded water, essential in the first hours after concreting, is scarce, which requires extra attention during the curing process. The samples were demoulded after $24 \mathrm{~h}$ and taken to the humid chamber, where they remained until they reached testing age.

\subsection{Experimental Procedures}

The experimental program was based on the recommendations of the Brazilian standard NBR 16416 [42], which regulates the use of pervious concrete pavements in Brazil. The tests were carried out to evaluate the influence of the considered parameters on the developed pervious concrete's mechanical and hydraulic properties. Hydraulic conductivity indices included density, voids index, and permeability coefficient. Mechanical parameters involved compressive strength, flexural strength, and modulus of elasticity. For the reference concrete case, the mechanical parameters of compressive strength and modulus of elasticity were analysed. The considered tests, the standards that specify them, the sample dimensions, the age of the test, and the number of samples are summarised in Table 4. 
Table 4. Dimensions and specifications of the specimens considered.

\begin{tabular}{|c|c|c|c|c|}
\hline Properties & Standard & Dimensions & Age of Testing & Number of Specimens \\
\hline Fresh Density & NBR 9833 [46] & - & After mixing & 3 (laboratory tests); 3 (case study) \\
\hline $\begin{array}{l}\text { Hardened } \\
\text { Density and } \\
\text { Voids Index }\end{array}$ & ASTM C 1754 [47] & $\begin{array}{c}10 \times 20 \mathrm{~cm} \text { (cylinders) } \\
10 \times 20 \times 6 \mathrm{~cm} ; \\
10 \times 20 \times 8 \mathrm{~cm}\end{array}$ & 28 days & $\begin{array}{c}12 \text { cylinders; } 15 \text { ( } 6 \mathrm{~cm} \text { thick); } \\
15 \text { ( } 8 \mathrm{~cm} \text { thick })\end{array}$ \\
\hline $\begin{array}{l}\text { Compressive } \\
\text { Strength }\end{array}$ & $\begin{array}{l}\text { NBR } 5739 \text { [48] and } \\
\text { NBR } 9781 \text { [49] }\end{array}$ & $\begin{array}{c}10 \times 20 \mathrm{~cm}(\text { cylinders }) \\
10 \times 20 \times 6 \mathrm{~cm} \\
10 \times 20 \times 8 \mathrm{~cm}\end{array}$ & 28 days & $\begin{array}{l}24 \text { cylinders (12 of pervious } \\
\text { concrete; } 12 \text { of conventional } \\
\text { concrete); } 15 \text { ( } 6 \mathrm{~cm} \text { thick); } \\
15 \text { ( } 8 \mathrm{~cm} \text { thick) }\end{array}$ \\
\hline $\begin{array}{l}\text { Flexural } \\
\text { Strength }\end{array}$ & NBR 12142 [50] & $45 \times 45 \times 15 \mathrm{~cm}$ & 28 days & 3 (laboratory tests); 3 (case study) \\
\hline $\begin{array}{l}\text { Modulus of } \\
\text { Elasticity }\end{array}$ & ASTM C 597 [51] & $10 \times 20 \mathrm{~cm}$ (cylinders) & 28 days & $\begin{array}{c}12 \text { (pervious concrete); } \\
12 \text { (conventional concrete) }\end{array}$ \\
\hline $\begin{array}{l}\text { Permeability } \\
\text { Coefficient }\end{array}$ & NBR 16416 [42] & $\begin{array}{l}75 \times 75 \times 6 \mathrm{~cm} \\
75 \times 75 \times 8 \mathrm{~cm}\end{array}$ & 28 days & 3 (6 cm thick); 3 ( $8 \mathrm{~cm}$ thick) \\
\hline
\end{tabular}

Moreover, the pervious concrete developed in this work was compared with different studies where there is a total substitution of natural aggregates with recycled aggregates. These references and their respective features are presented in Table 5.

Table 5. Proportions of the mixes used to compare the analysed parameters.

\begin{tabular}{|c|c|c|c|c|c|c|c|}
\hline Study & $\begin{array}{c}\text { Mix } \\
\text { Identification }\end{array}$ & $\begin{array}{l}\text { Cement } \\
\left(\mathrm{kg} / \mathrm{m}^{3}\right)\end{array}$ & $\begin{array}{l}\text { Silica } \\
\text { Fume } \\
\left(\mathrm{kg} / \mathrm{m}^{3}\right)\end{array}$ & $\begin{array}{c}\text { Gravel (Natural } \\
\text { Aggregate) } \\
\left(\mathrm{kg} / \mathrm{m}^{3}\right)\end{array}$ & $\begin{array}{l}\text { Recycled } \\
\text { Aggregate } \\
\left(\mathrm{kg} / \mathrm{m}^{3}\right)\end{array}$ & $\begin{array}{c}\text { Water } \\
\left(\mathrm{kg} / \mathrm{m}^{3}\right)\end{array}$ & $\begin{array}{c}\text { Additive } \\
\left(\mathrm{kg} / \mathrm{m}^{3}\right)\end{array}$ \\
\hline \multirow{2}{*}{ Zaetang et al. [4] } & Z-R0 & 316 & - & 1435 & - & 76 & 2.4 \\
\hline & Z-R100 & 316 & - & - & 1435 & 76 & 2.4 \\
\hline \multirow{2}{*}{ Yap et al. [3] } & Y-R0 & 359 & - & 1300 & - & 125 & - \\
\hline & Y-R100 & 359 & - & - & 1484 & 125 & - \\
\hline \multirow{2}{*}{ El-Hassan et al. [10] } & E-R0 & 580 & - & 1404 & - & 232 & - \\
\hline & E-R100 & 500 & - & - & 1325 & 200 & - \\
\hline \multirow{2}{*}{ Lu et al. [14] } & L-R0 & 272 & 30 & 1510 & - & 97 & - \\
\hline & L-R100 & 272 & 30 & - & 1510 & 136 & - \\
\hline \multirow{2}{*}{ Vieira et al. [52] } & V-R0 & 516 & - & 2063 & - & 155 & - \\
\hline & V-R100 & 448 & - & - & 1790 & 134 & - \\
\hline
\end{tabular}

Each study was selected for comparison due to a particular feature: Zaetang et al. [4] added a superplasticiser Type $\mathrm{F}$ to their mixtures; Yap et al. [3] used a smaller particle size of recycled aggregates in their compositions (4.5 to $9.5 \mathrm{~mm}$ ); El-Hassan et al. [10] established a design porosity of $10 \%$, which increased the cement content of the composite; $\mathrm{Lu}$ et al. [14] also studied the incorporation of silica fume in their pervious concrete, intending to mitigate the reduction in its compressive strength; and finally, Vieira et al. [52], despite not using RCA exclusively but recycled aggregates from CDW, used the same cement from this study as a binder (CP V). For the other studies, ASTM type I ordinary Portland cement was used. The comparison with these studies also extends to the analysis of the concretes' environmental performance to identify and contextualise the sustainable potential of the product developed in this research. 


\subsubsection{Fresh Density}

The methodology used to perform the fresh density test is described in NBR 9833 [46]. This standard is based on the recommendations of ASTM C 1688 [53]. The test was performed by moulding a container with a capacity of $5 \mathrm{dm}^{3}$, whose characteristics are specified by the reference standard. The concrete was distributed in two layers, applying 20 socket strokes per layer. Finally, the test was completed by dividing the mass of material obtained by the container's volume. According to Tennis et al. [26], pervious concrete shows fresh density values $30 \%$ lower than those demonstrated by conventional concretes.

\subsubsection{Hardened Density and Voids Index}

The hardened density, defined as the relationship between each specimen's mass and its total volume, was determined using the methods described in ASTM C 1754 [47], specified for pervious concretes. According to this international standard, the porosity (voids index) of the samples was evaluated. For this, the dry mass and the submerged mass of each specimen were obtained, with the aid of a hydrostatic scale. The void index was calculated using Equation (1), which correlates each sample's mass with the respective volume.

$$
I v=\left(1-\frac{M_{d r y}-M_{s u b}}{\gamma_{w} V o l}\right)
$$

where $I_{v}$ is the void index of the specimen; $M_{d r y}$ is the dry mass (kg); $M_{s u b}$ is the submerged mass $(\mathrm{kg}) ; \gamma_{w}$ is the apparent density of water $\left(\mathrm{kg} / \mathrm{m}^{3}\right)$; and $\mathrm{Vol}$ is the specimen volume $\left(\mathrm{m}^{3}\right)$.

\subsubsection{Compressive Strength}

The procedures performed on the cylindrical samples followed the recommendations of NBR 5739 [48], which meets the methodology present in ASTM C39 [54]. Although this test is not provided in NBR 16416 [42], its application aims to establish a parallel between the pervious concrete developed and the other reference concretes. The tests were carried out in a CONTENCO electro-hydraulic press, with a capacity of $100 \mathrm{~T}$ and a resolution of $10 \mathrm{kgf}$. The rupture strengths were calculated using Equation (2):

$$
f_{c}=\frac{4 F}{\pi D^{2}}
$$

where $f_{c}$ is compressive strength (MPa); $F$ is the breaking load $(\mathrm{N})$; and $D$ is the diameter of the specimen $(\mathrm{mm})$.

The guidelines for carrying out this test are established in NBR 9781 [49]. The execution of the laboratory procedure must simulate the stress borne by the piece during its use as a floor. Therefore, the test consisted of applying a continuous load on the specimen until its complete rupture, using the same press mentioned before. The compressive strength of each piece (MPa) was obtained by dividing the breaking load $(\mathrm{N})$ by the loading area $\left(\mathrm{mm}^{2}\right)$. The test result still involved multiplication by a correction factor $(\mathrm{p})$ corresponding to the piece's nominal thickness. According to normative specifications, $\mathrm{p}$ is 0.95 for pieces with a thickness equal to $6 \mathrm{~cm}$, and 1.00 for those equal to $8 \mathrm{~cm}$.

Finally, the standard recommends quantifying the estimated compressive strength $\left(f_{p k, e s t}\right)$ using Student's t-coefficient as a function of sampling, assuming that the compressive strengths follow a normal distribution (Equation (3)). Student's t-distribution is a theoretical probability distribution similar to the standard normal curve, but with wider tails. It is useful when estimating the mean of a normally distributed population in situations where the sample size is small and the population's standard deviation is unknown [55].

$$
f_{p k, e s t}=f_{p}-t \times s
$$


where $f_{p}$ is the average compressive strength of the pieces (MPa); $f_{p k, e s t}$ is the estimated compressive strength (MPa); $s$ is the standard deviation of the sampling $(\mathrm{MPa})$; and $t$ is Student's t-coefficient (with an $80 \%$ confidence interval).

\subsubsection{Flexural Strength}

The flexural strength test followed NBR 12142 [50], which is based on the recommendations of ASTM C1161 [56]. This test also corresponds to a normative requirement, specifically for pervious concrete moulded "in situ". The press used in this procedure is the same as the one described in the previous tests. Flexural strength was calculated according to Equation (4).

$$
f_{c, f}=\frac{F l}{b d^{2}}
$$

where $f_{c, f}$ is the flexural strength (MPa); $F$ is the breaking load $(\mathrm{N}) ; l$ is the distance between the supports (mm); $b$ is the average width of the specimen ( $\mathrm{mm})$; and $d$ is the average height of the specimen ( $\mathrm{mm}$ ).

\subsubsection{Modulus of Elasticity}

The analysis of the dynamic modulus of elasticity of the concrete presents as a criterion the speed of propagation of ultrasonic waves in the composite. According to ASTM C 597 [51], its methodology is based on the basic concept of interdependence between the speed of propagation of longitudinal waves in a homogeneous and isotropic material and the elastic constants of this material. The propagation speed of each specimen was obtained using the ultrasound device TICO, and the dynamic modulus of elasticity was calculated using Equation (5).

$$
E_{d}=\gamma S^{2} \frac{(1+v)(1-2 v)}{(1-v)}
$$

where $E_{d}$ is the dynamic modulus of elasticity (MPa); $\gamma$ is the specific mass of the material $\left(\mathrm{kg} / \mathrm{m}^{3}\right) ; S$ is the wave propagation speed $(\mathrm{km} / \mathrm{s})$; and $v$ is Poisson's ratio of pervious concrete, which, according to Goede [57], is equal to 0.22 .

\subsubsection{Permeability Coefficient}

Permeability is one of the most important properties for pervious concrete, as it is essential for the management of rainwater in urban drainage systems [14]. NBR 16416 [42] admits two methods for assessing the permeability coefficient in the laboratory: the constanthead method, described by NBR 13292 [58], and the test described in the standard, based on ASTM C170 [59]. Due to its practicality, the test method presented in the standard was used (Figure 3).

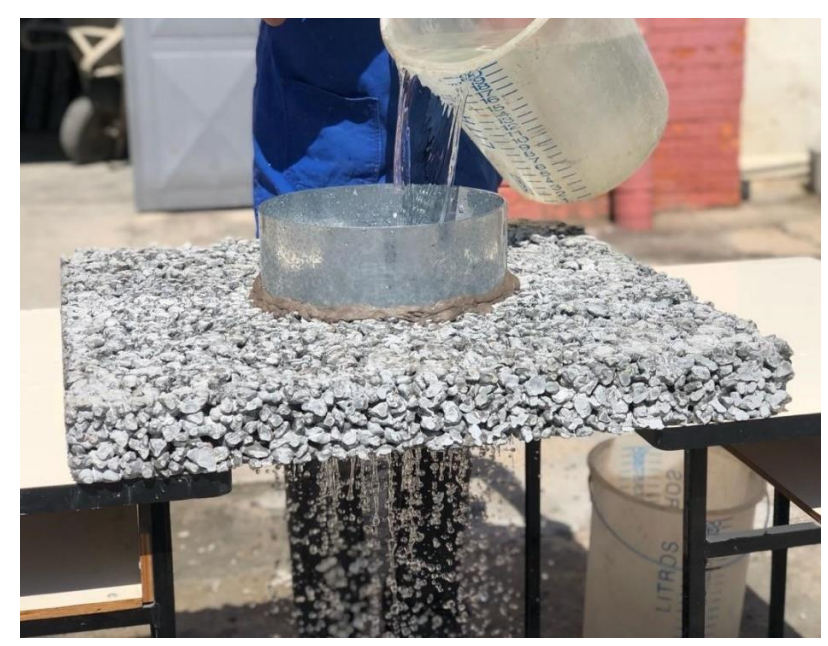

Figure 3. Permeability coefficient test. 
Besides, the standard limits the performance of permeability tests in the field to the chosen technique. In this way, it is possible to perform the test on the samples in the laboratory and directly in the implemented case study, comparing the obtained results later. Measuring the infiltration time (T) and the infiltrated water mass $(M)$ used in the test, the permeability coefficient $(K)$ was determined by Equation (6):

$$
K=\frac{C M}{D^{2} T}
$$

where $K$ is the permeability coefficient, in $\mathrm{mm} / \mathrm{h}$; $C$ is the international system unit conversion factor $(4,583,666,000) ; M$ is the infiltrated water mass, in $\mathrm{kg}$; and $D$ is the internal diameter of the infiltration cylinder $(300 \mathrm{~mm})$, in the time $(T)$ it takes the water mass to infiltrate, in seconds.

\subsubsection{Microstructural and Mineralogical Analysis}

In cooperation with the Brazilian Portland Cement Association (ABCP), transmitted light microscopy (TLM) and X-ray diffractometry (XRD) tests were carried out on a fractured sample of pervious concrete to study how the incorporation of RCA affects its structure. TLM was used to analyse the interaction between the paste and the recycled aggregate. The microscope was adjusted at a magnification of up to $50 \times$ to obtain a clear image of the transition zone between the phases. XRD aimed to extract the analysis of the pervious concrete's morphology and composition.

\subsection{Pilot-Scale Case Study}

For the "in situ" assessment of the studied material's hydraulic properties, a case study consisting of pervious concrete was implemented: a $2.5 \times 5.0 \mathrm{~m}$ parking space, located in the Infrastructure Office of UFJF (ProInfra) parking lot (Figure 4a). Following the recommendations of NBR 16416 [42], the parking space had a pervious concrete lining moulded in place with a thickness of $10 \mathrm{~cm}$. For the lower layer, for which a thickness of $30 \mathrm{~cm}$ was adopted, open-grain stone materials were used, as specified in the standard (Figure $4 \mathrm{~b}$ ). According to the subgrade characteristics, a partial drainage system was adopted, where a small part of the precipitated water infiltrates through the soil itself and the rest is removed by the installed drain, given a $2 \%$ drop, after being temporarily stored in the porous structure.

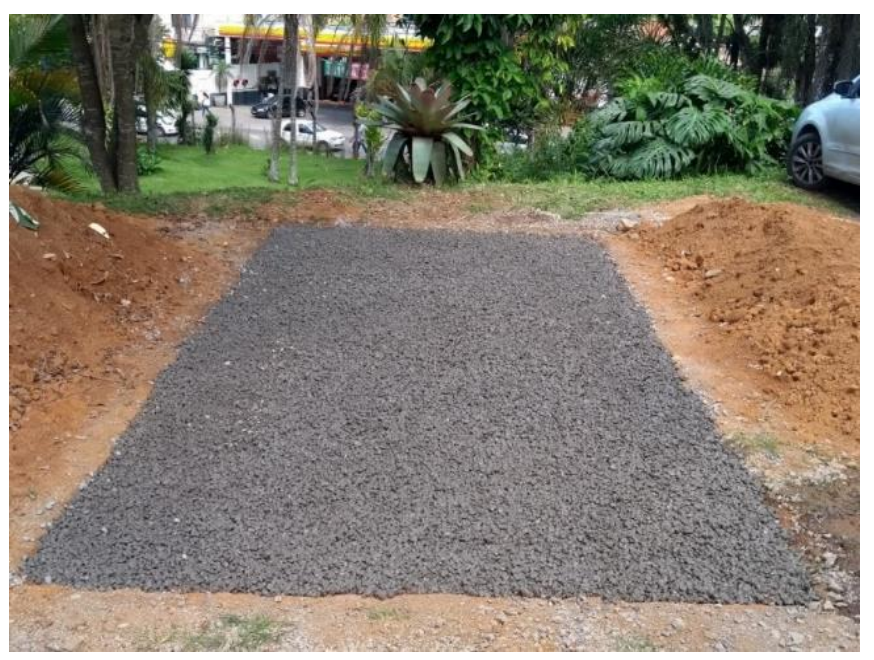

(a)

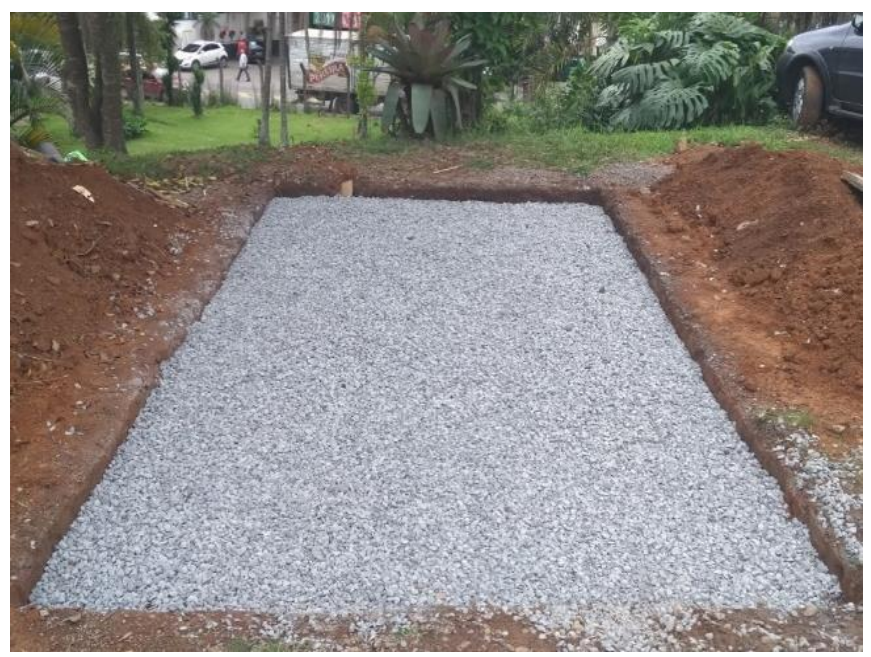

(b)

Figure 4. Parking space lined with recycled concrete aggregate (RCA)-based pervious concrete (a) and seated sub-base layer (b). 
The mixing of the materials was carried out according to the parameters previously defined in the laboratory. The concrete was launched directly with the wheelbarrow, spread over the interior of the parking space, compacted manually with the aid of a trowel, and levelled with a wooden batten to accommodate the particles in regular layers and to regularise the surface (Figure 5).

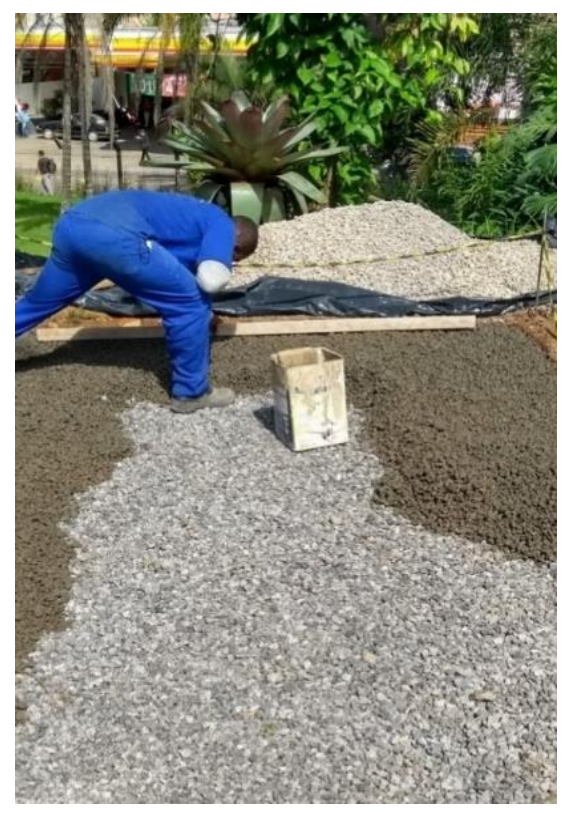

(a)

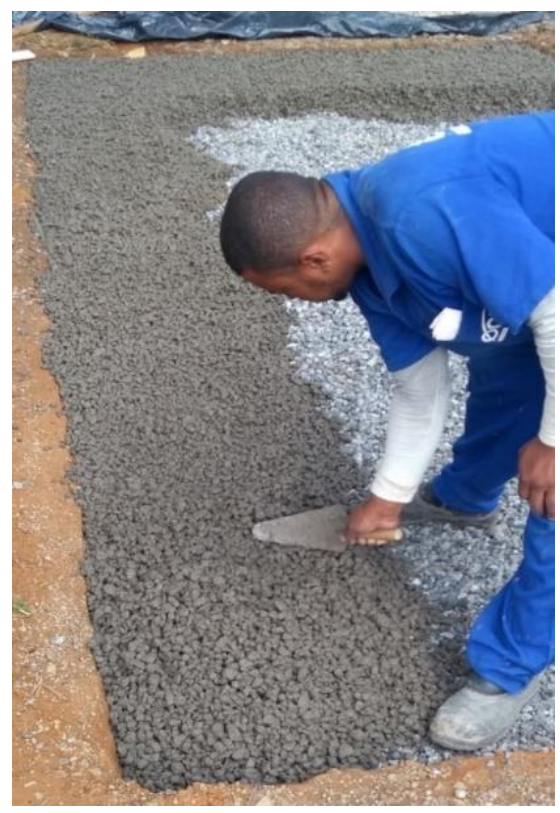

(b)

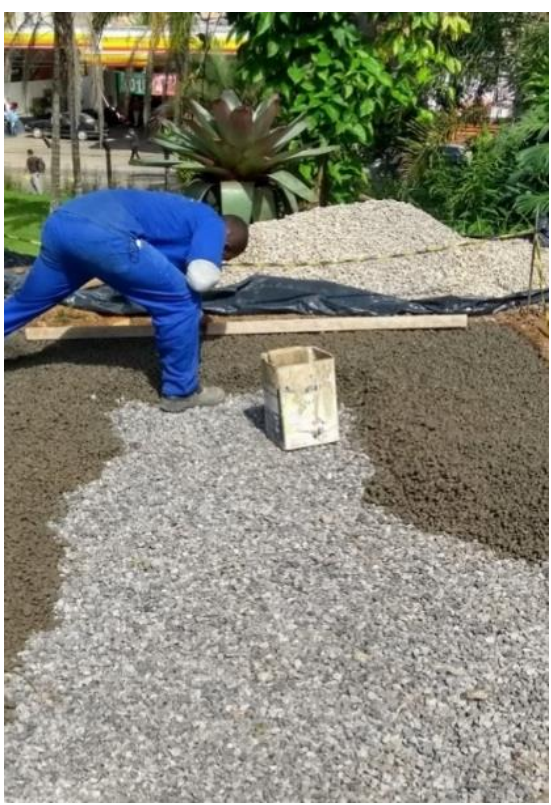

(c)

Figure 5. Launch (a), compaction (b), and levelling (c) of the pervious concrete moulded "in situ".

No expansion joints were created in the coating. According to the National Ready Mixed Concrete Association (NRMCA) [60], concreting "in situ" allows the absence of joints in plates less than $6 \mathrm{~m}$ in length due to the lower shrinkage presented by pervious concrete over conventional. The curing of the material consisted of wetting of the concrete at regular periods by ProInfra employees for 7 days. After this initial period, the permeability coefficient tests were performed. In addition to the permeability coefficient test in the case study, when concreting the parking space, the fresh density test was performed, and 3 prisms were moulded for the flexural strength test, as recommended by the standard of reference.

\subsection{Environmental Performance Assessment \\ 2.5.1. Goal and Scope}

The main goal was to evaluate the environmental performance of different concrete mixes using recycled aggregates instead of natural ones, including those developed in this work and those taken from the literature (Table 5). The method used in this study followed the phases of a Life Cycle Assessment (LCA): objective and scope definition, inventory analysis, and impact assessment. Comparative analysis and aggregation of indicators were developed using the multi-criteria decision support Methodology for the Relative Sustainability Assessment of Building Technologies (MARS-SC) [61-63]. The MARS-SC methodology is based on assessing the impact of a construction solution on three groups of sustainability dimensions: environmental, functional, and economic [62,63]. As this research aims to assess the environmental performance of different concrete formulations, only the environmental dimension of MARS-SC was considered. 


\subsubsection{Declared Unit and System Boundaries}

The declared unit was $1 \mathrm{~m}^{3}$ of concrete, which is the basis for comparison throughout the study. The boundaries of this research include the embodied environmental impacts (cradle-to-gate) of the different concrete compositions, comprising the extraction of raw materials for concrete production and preparation processes (cement, recycled aggregate, artificial and natural sand, gravel, silica fume, and plasticiser) and the environmental impacts that result from the transportation of materials to the concrete plant and their mixing. The option to limit the study to the cradle-to-gate stage is justified because the use and disposal of concrete will result in similar environmental impacts in the studied compositions.

\subsubsection{Inventory Analysis}

Inventory analysis was used to quantify the inputs (e.g., energy and materials) and outputs (e.g., emissions and waste) of the product system $[29,64]$. As previously mentioned, in this study, the production of raw material, its transport to the concrete plant, and concrete production were included in the inventory.

The inventory of materials corresponds to the mix proportions presented in Tables 3 and 5 . The transportation inventory considered for the specific context of the Brazilian concrete industry is shown in Table 6. The impacts were calculated using the Life Cycle Impact Assessment (LCIA) methods, and the SimaPro 8.4.0.0 software was used to model the life cycle of the different mixtures.

Table 6. Results of the transportation inventory for each concrete mix (figures per $\mathrm{m}^{3}$ of produced concrete).

\begin{tabular}{|c|c|c|c|c|c|c|c|c|c|}
\hline \multirow{2}{*}{ Concrete Identification } & \multirow{2}{*}{ Cement } & \multirow{2}{*}{ Silica Fume } & \multirow{2}{*}{ Gravel } & \multicolumn{2}{|c|}{ Recycled Aggregate } & \multirow{2}{*}{ AS } & \multirow{2}{*}{ NS } & \multirow{2}{*}{ Additive } & \multirow{2}{*}{ Unity } \\
\hline & & & & Scenario 1 & Scenario 2 & & & & \\
\hline CC-Ref-R0 & 57 & 0 & 17 & 0 & 0 & 4 & 11 & 0 & $\mathrm{tkm}$ \\
\hline PC-R100 & 56 & 0 & 0 & 208 & 20 & 0 & 0 & 0 & $\mathrm{tkm}$ \\
\hline Z-R0 & 57 & 0 & 24 & 0 & 0 & 0 & 0 & 0 & $\mathrm{tkm}$ \\
\hline Z-R100 & 57 & 0 & 0 & 253 & 24 & 0 & 0 & 0 & $\mathrm{tkm}$ \\
\hline Y-R0 & 64 & 0 & 22 & 0 & 0 & 0 & 0 & 0 & $\mathrm{tkm}$ \\
\hline Y-R100 & 64 & 0 & 0 & 261 & 25 & 0 & 0 & 0 & $\mathrm{tkm}$ \\
\hline E-R0 & 104 & 0 & 23 & 0 & 0 & 0 & 0 & 0 & $\mathrm{tkm}$ \\
\hline E-R100 & 90 & 0 & 0 & 233 & 22 & 0 & 0 & 0 & $\mathrm{tkm}$ \\
\hline L-R0 & 49 & 16 & 25 & 0 & 0 & 0 & 0 & 0 & $\mathrm{tkm}$ \\
\hline L-R100 & 49 & 16 & 0 & 266 & 25 & 0 & 0 & 0 & $\mathrm{tkm}$ \\
\hline V-R0 & 92 & 0 & 34 & 0 & 0 & 0 & 0 & 0 & $\mathrm{tkm}$ \\
\hline V-R100 & 80 & 0 & 0 & 315 & 30 & 0 & 0 & 0 & $\mathrm{tkm}$ \\
\hline
\end{tabular}

For the CP III and CP V types of cement, the consumption of raw materials, energy, and fuel and the emissions released during cement production of a Brazilian cement plant were considered. The used source of information was the public Product Environmental Declaration of the selected cement plant [65].

For recycled aggregates, two scenarios were analysed regarding their transport. The first scenario considers the transport from a waste treatment plant located $176 \mathrm{~km}$ away from the reference concrete plant. In the second scenario, the recycled aggregates are transported for the same distance of the natural aggregates. In Brazil, CDWs are classified as a waste product and, therefore, do not afford an economic value. Thus, according to the allocation rules established by ISO 14040 [66], no flows from the demolition site were attributed to the waste treatment plant and its production. Only the transportation from the production site to the concrete plant was considered.

The other materials used in the mixtures (Type 1 cement, sand, gravel, silica fume, and additives), transportation processes, and production processes and generic data from the life cycle inventory database Ecoinvent report V3 [67] were used. This database covers the average inventory data of the primary building materials and processes in different regional contexts [62]. For each considered process from this database, a contextualisation 
was made for the Brazilian energy context. Therefore, all the processes used from the Ecoinvent database were edited, and the electricity input flows were changed considering the Brazilian energy mix.

\subsubsection{Impact Assessment}

In this stage, the classification, characterisation, and normalisation of the impact categories were carried out [31]. Life cycle inventory data were converted into potential environmental impacts, using different LCIA methods. In MARS-SC, the environmental performance assessment is based on the following categories of environmental impact (Table 7): global warming, ozone depletion, soil and water acidification, eutrophication, photochemical ozone creation, and depletion of abiotic resources-fossils fuels. Compared to the list of impact categories found in the EN 15804 standard [68], MARS-SC does not consider the depletion of abiotic resources elements as an impact category.

Table 7. Indicators, units, and life cycle impact assessment (LCIA) methods.

\begin{tabular}{ccc}
\hline Environmental Indicators & Units & LCIA Methods \\
\hline Global Warming (GWP 100) & $\left(\mathrm{kg} \mathrm{CO}_{2}\right.$ eq $)$ & CML-IA baseline V3.04 \\
Ozone Layer Depletion (ODP) & $(\mathrm{kg} \mathrm{CFC-11} \mathrm{eq)}$ & CML-IA baseline V3.04 \\
Acidification Potential (AP) & $\left(\mathrm{kg} \mathrm{SO}_{2}\right.$ eq) & CML-IA baseline V3.04 \\
Eutrophication Potential (EP) & $\left(\mathrm{kg} \mathrm{PO}_{4}\right.$ eq) & CML-IA baseline V3.04 \\
Formation Potential of Tropospheric Ozone (POCP) & $\left(\mathrm{kg} \mathrm{C}_{2} \mathrm{H}_{4} \mathrm{eq}\right)$ & CML-IA baseline V3.04 \\
Abiotic Depletion Potential of Fossil Resources (ADP_FF) & (MJ eq) & CML-IA baseline V3.04 \\
\hline
\end{tabular}

\subsubsection{Normalisation and Aggregation}

To avoid scale effects in the aggregation of the parameters of the different indicators, and because some of the parameters are of the type where "higher is better" and others where "lower is better", the indicators needed to be normalised [29]. The normalisation of indicators was performed as described in $[62,63]$.

The aggregation of each environmental indicator into a global indicator that describes the overall environmental performance was done according to the procedure described in previous research [63]. The results were presented in a "radar" or Amoeba diagram, also known as a sustainable profile. In the diagram, the number of rays is equal to the number of indicators that were analysed [29]. In each sustainable profile, the overall performance of the different concretes is monitored and compared with the RCA-based pervious concrete developed in the study (Table 3).

\section{Results and Discussion}

\subsection{Transmitted Light Microscopy (TLM)}

The performance of pervious concrete is dependent on the cement paste, the cement content, the aggregates, the water/cement ratio, and, mainly, the pore structure $[52,69]$. When using the recycled aggregate, the concrete tends to present a more porous cement paste and larger interconnected voids. In Figure $6 \mathrm{a}$, from the photomicrograph with uncrossed nicols (polarised filters) at $25 \times$ magnification, it is possible to observe the RCA $(\mathrm{G})$ involved with the paste of cement $(\mathrm{P})$. In the lower portion of the image, a pore (poro) is identified. In Figure 6b, which shows the cross nicol photomicrograph, also with a $25 \times$ magnification, there is an abrupt contact between the paste $(\mathrm{P})$ and the recycled aggregate $(G)$.

Another important factor analysed involves the carbonation of the recycled concrete used. The cross nicols photomicrograph with 50× magnification presented in Figure 7 allows for evaluating the contact between the RCA $(G)$, which has its paste with a high degree of carbonation (arrow), and the non-carbonated paste (P). In Figure 7a, it is possible to notice, again, the abrupt contact between the paste and the recycled aggregate. Note that to the left of Figure $7 \mathrm{~b}$, next to the pore $(\mathrm{V})$, the paste $(\mathrm{P})$ is already carbonated (arrow). 
The contact between the paste $(\mathrm{P})$ and the recycled aggregate takes place gradually, giving rise to a transition zone $(\mathrm{Z})$.

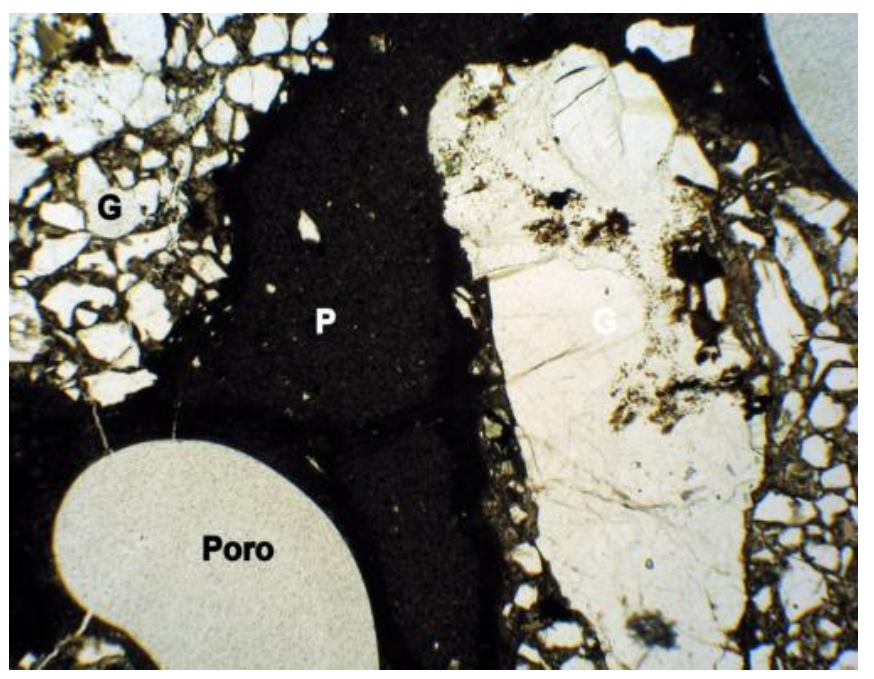

(a)

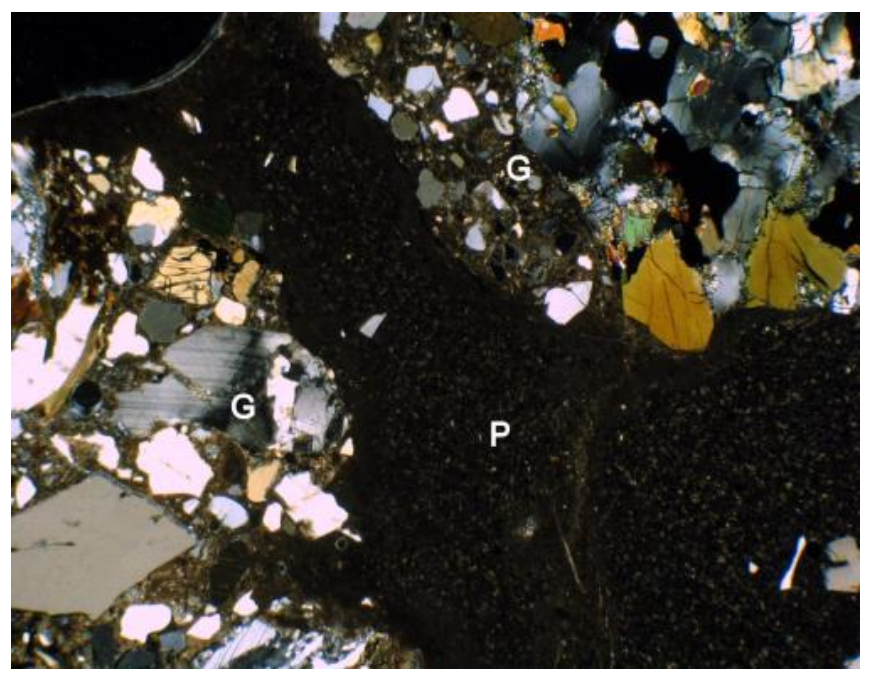

(b)

Figure 6. Photomicrograph with uncrossed (a) and crossed (b) nicols, transmitted light microscope, $25 \times$ magnification.

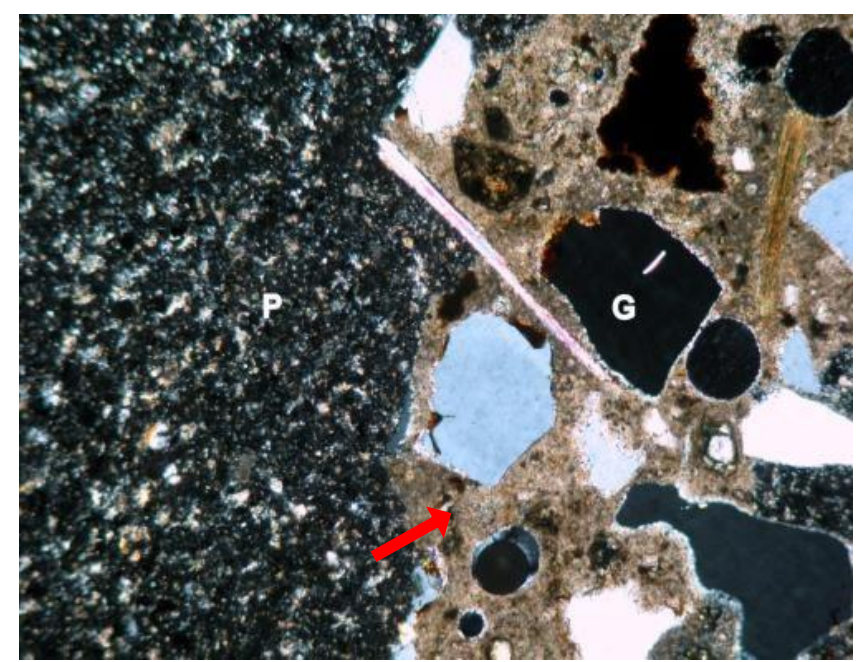

(a)

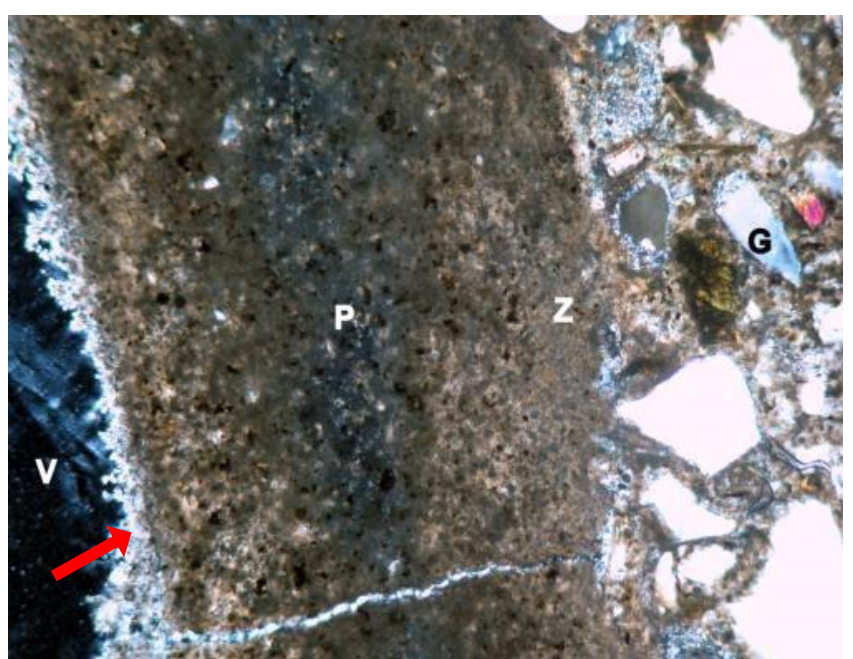

(b)

Figure 7. Cross nicol photomicrograph (a) and (b), transmitted light microscope, $50 \times$ magnification.

In another two points of the sample, a cross nicol photomicrograph with $50 \times$ magnification (Figure 8) shows the contact between the carbonated RCA (G) and the lowcarbonated paste $(\mathrm{P})$. The contact also occurs gradually, giving rise to a new transition zone (Z).

According to Yang et al. [70], pervious concrete with recycled aggregates presents a less dense paste, since the transition zone between the phases is more visible. Yap et al. [3] point out that the strength of this aggregate-paste bond is lower in concretes with higher replacement of natural aggregates by RCA, which has trapped and permeable pores. This phenomenon is due to the absorption of the mixing water by the mortar adhered to the RCA, which reduces the amount of cement paste [5]. 


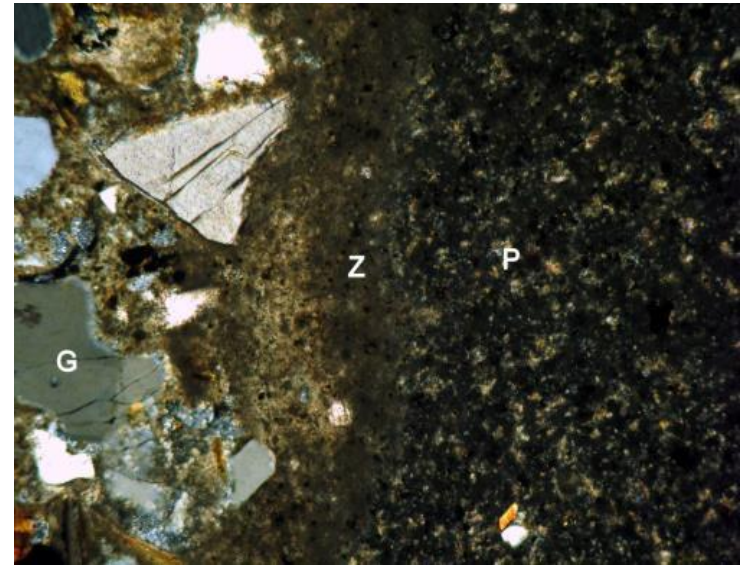

(a)

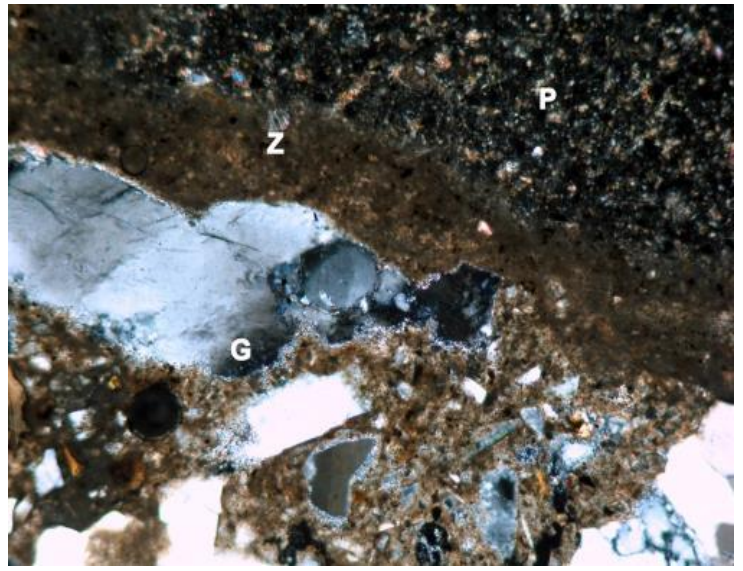

(b)

Figure 8. Cross nicol photomicrograph (a) and (b), transmitted light microscope, $50 \times$ magnification.

The presence of cracks also makes the structure weaker [71]. Wang, $\mathrm{Yu}$, and Li [72] clarify that this fragility in the transition zone is caused by the processing of RCA (crushing and screening), which is also responsible for the increase in porosity. If, on the one hand, RCA porosity in pervious concrete is beneficial considering the permeability and infiltration criteria, on the other hand, its fragile microstructure, with a large number of micro-cracks in the transition zone, has a significant impact on the physical-mechanical properties of the composite.

\subsection{X-ray Diffractometry (XRD)}

Figure 9 presents the diffractogram of the fractured sample of pervious concrete. After preparation of the recycled aggregate, XRD shows that the concrete produced comprises minerals related to RCA: quartz, feldspar, mica, and pyroxene. In addition to these, it is possible to identify portlandite $\left(\mathrm{Ca}(\mathrm{OH})_{2}\right)$, calcite, and anhydrous cement minerals, suggesting the presence of the adhered mortar phase.

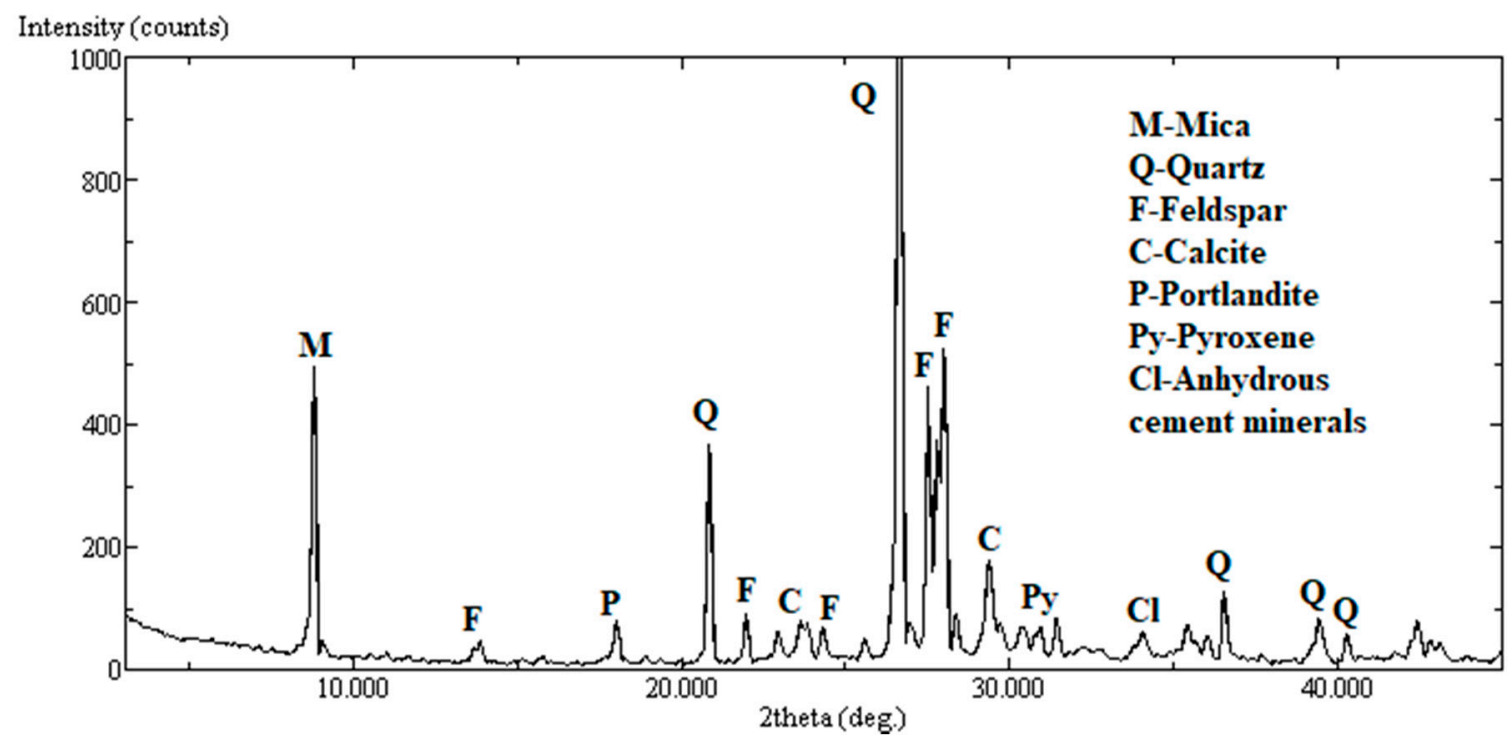

Figure 9. X-ray diffraction.

In general, the transition zones between the phases represent the most fragile places in the concrete. The incidence of any variations such as the appearance of cracks or increased porosity is capable of causing a loss of adhesion between the phases, affecting the mechanical properties of the concrete [73]. The results of the microstructural and 
composition analyses suggested that the rupture of the RCA-based pervious concrete occurs mainly at the interface between the recycled aggregate and the old, adhered cement paste.

\subsection{Void Index and Fresh and Hardened Density}

The fresh density tests performed in the laboratory showed an average of $1678.9 \mathrm{~kg} / \mathrm{m}^{3}$, with a standard deviation of $54.96 \mathrm{~kg} / \mathrm{m}^{3}$ and a coefficient of variation of $3.27 \%$. According to NBR 16416 [42], the value obtained must be equal to that specified in the project $\left(1600 \mathrm{~kg} / \mathrm{m}^{3}\right)$, with a tolerance of $80 \mathrm{~kg} / \mathrm{m}^{3}$. As noted, the result obtained respects the normative regulations. Table 8 presents the average, standard deviation, and the variation coefficient of the results of the hardened density and void index related to each type of pervious concrete specimen tested.

Table 8. Results of hardened density and voids index of RCA-based pervious concrete.

\begin{tabular}{|c|c|c|c|c|c|c|}
\hline \multirow[b]{2}{*}{ Data } & \multicolumn{2}{|c|}{ Cylindrical Specimens } & \multicolumn{2}{|c|}{ Pieces $10 \times 20 \times 6 \mathrm{~cm}$} & \multicolumn{2}{|c|}{ Pieces $10 \times 20 \times 8 \mathrm{~cm}$} \\
\hline & $\begin{array}{l}\text { Hardened Density } \\
\left(\mathrm{kg} / \mathrm{m}^{3}\right)\end{array}$ & $\begin{array}{l}\text { Void Index } \\
(\%)\end{array}$ & $\begin{array}{l}\text { Hardened Density } \\
\left(\mathrm{kg} / \mathrm{m}^{3}\right)\end{array}$ & $\begin{array}{l}\text { Void Index } \\
(\%)\end{array}$ & $\begin{array}{l}\text { Hardened Density } \\
\left(\mathrm{kg} / \mathrm{m}^{3}\right)\end{array}$ & $\begin{array}{l}\text { Void Index } \\
(\%)\end{array}$ \\
\hline Average & 1904.33 & 24.83 & 2006.57 & 16.94 & 1840.24 & 17.88 \\
\hline $\begin{array}{l}\text { Standard } \\
\text { Deviation }\end{array}$ & 96.30 & 3.16 & 104.28 & 2.31 & 98.65 & 2.40 \\
\hline $\begin{array}{l}\text { Coefficient of } \\
\text { Variation (\%) }\end{array}$ & 5.06 & 12.74 & 5.20 & 13.63 & 5.36 & 13.40 \\
\hline
\end{tabular}

Although the literature indicates values from 15\% to $35 \%$ for the typical void index of pervious concrete, the rates obtained are closer to the $20 \%$ defined by Tennis et al. [26] as the optimal value between resistance and permeability. In general, the use of RCA decreases the hardened density of pervious concrete. According to Kim et al. [74], higher values of porosity and absorption are associated with an increase in recycled aggregate index in concrete. This behaviour can be attributed to the lower density and the higher void index of the recycled aggregate itself [2]. Due to its texture and more angular shape, more trapped air is introduced into the concrete. However, it is also possible that this behaviour is due to the lower adherence of the mortar on the RCA, resulting in a more porous concrete structure [10].

The correlation between hardened density and void index can be seen in Figure 10. It is noticeable that the void index represents a dominant factor over the hardening density of pervious concrete.

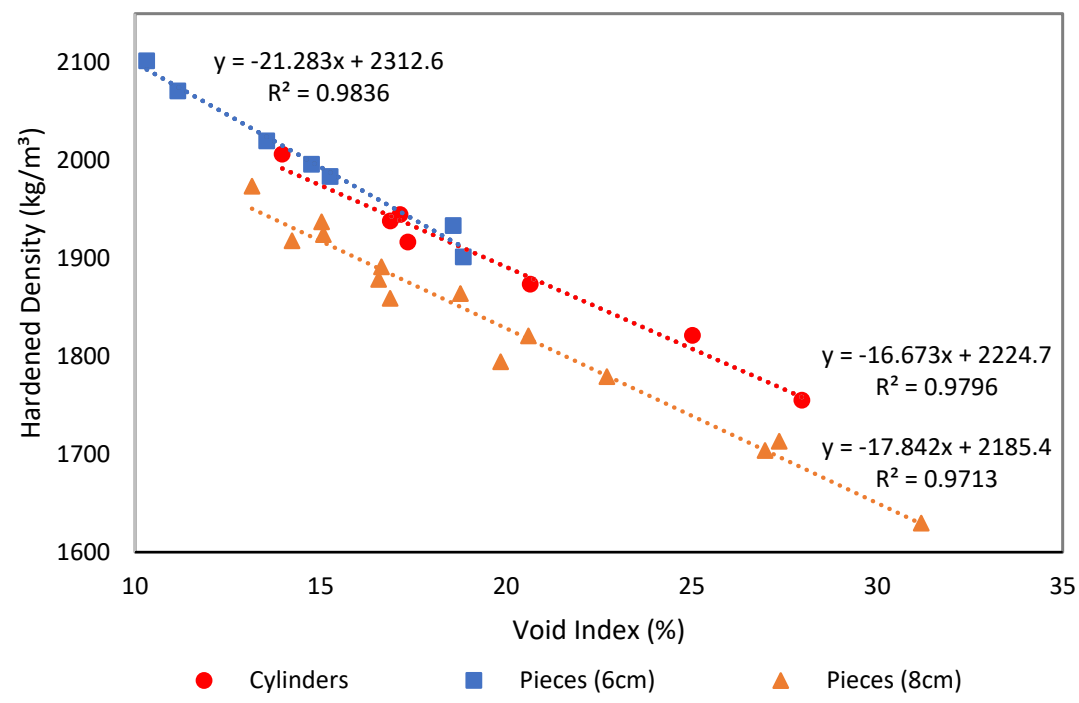

Figure 10. Correlation between hardened density and void index. 
The cylindrical specimens and the 6 and $8 \mathrm{~cm}$ pieces for interlocking paving presented an average hardened density $18 \%, 25 \%$, and $16 \%$ higher than the design value, respectively. This discrepancy between the different specimens is mainly due to the difference between the volume of voids desired and that actually obtained. It is worth mentioning the dependence of these properties on the RCA variability used in the mixture and the concrete compaction procedures.

\subsection{Compressive Strength}

The compressive strength results obtained for concrete pieces of 6 and $8 \mathrm{~cm}$ thickness are shown in Table 9.

Table 9. Results of compressive strength obtained for concrete pieces of 6 and $8 \mathrm{~cm}$ thickness.

\begin{tabular}{ccc}
\hline Data & $\mathbf{6} \mathbf{~ c m}$ Thick & $\mathbf{8} \mathbf{~ c m}$ Thick \\
\hline Average $(\mathrm{MPa})$ & 24.30 & 21.91 \\
Standard Deviation $(\mathrm{MPa})$ & 3.00 & 1.90 \\
Coefficient of Variation $(\%)$ & 12.36 & 8.68 \\
$f_{p k, \text { sst }}(\mathrm{MPa})$ & 21.64 & 20.21 \\
\hline
\end{tabular}

It is possible to notice that the values obtained for both thicknesses meet the normative requirements defined by NBR 16416 [42], limiting the compressive strength of permeable pieces for interlocked paving at $20 \mathrm{MPa}$. Therefore, this material can be used as a floor covering for pedestrian traffic, with a minimum thickness of $6 \mathrm{~cm}$, and light traffic, identified as requesting the pavement to preferential traffic of light vehicles (minimum thickness of $8 \mathrm{~cm})$.

However, even after applying the correction factor related to the sample thickness, the $6 \mathrm{~cm}$ pieces showed higher resistance than the thicker pieces. This phenomenon can be justified by analysing Figure 11, which demonstrates the proportionality relationship between the compressive strength and the hardened density of the pieces for interlocking paving: higher-density samples tend to have higher compressive strength indexes.

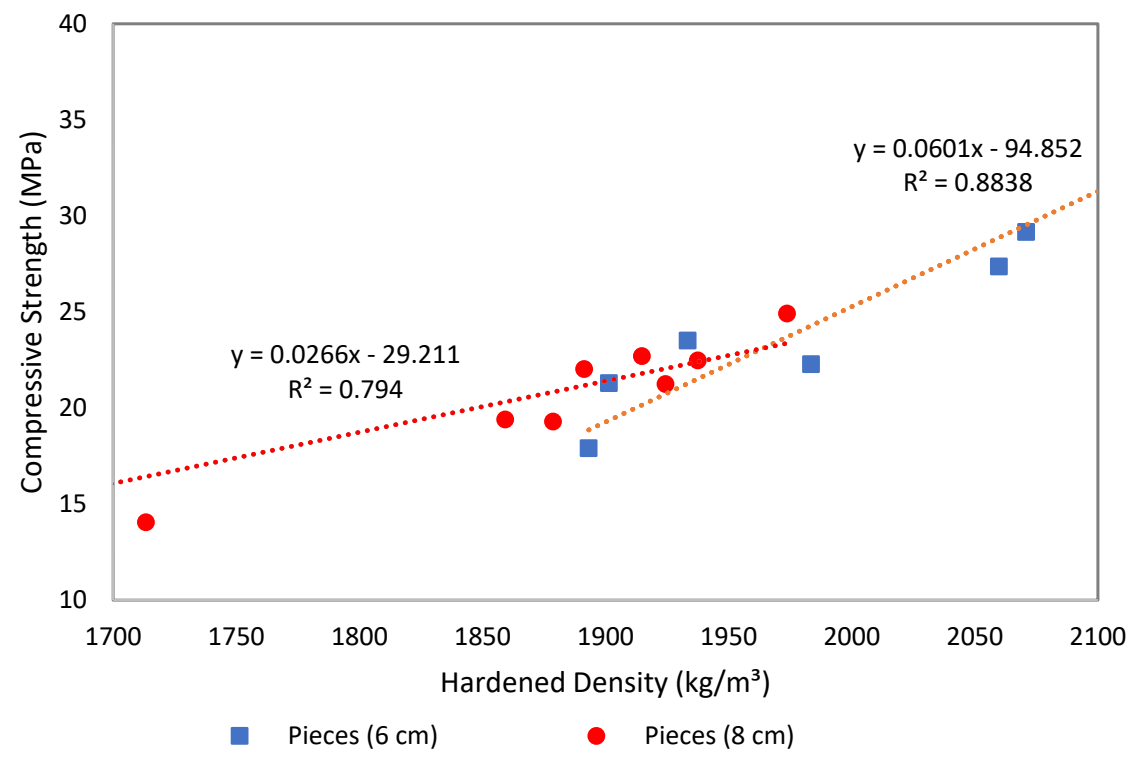

Figure 11. Correlation between compressive strength and the hardened density of the pieces for interlocking paving.

As seen, for both cases, the compressive strength tended to increase linearly with increasing density, which indicates that density plays a fundamental role in the mechanical strength of pervious concrete. Therefore, the lower compressive strength associated with 
$8 \mathrm{~cm}$ thick pieces is related to the lower indices of hardened density presented by them. Besides, according to Silva, Brito, and Dhir [75], the existence of different construction methods naturally reflects in recycled aggregates diversified in quality and composition, representing the production of new construction materials of varying quality.

The average values of compressive strength at 28 days obtained for cylindrical samples of pervious concrete and conventional concrete are shown in Table 10.

Table 10. Results of compressive strength and modulus of elasticity obtained for the cylindrical specimens.

\begin{tabular}{ccccc}
\hline \multirow{2}{*}{ Data } & \multicolumn{2}{c}{ Pervious Concrete } & \multicolumn{2}{c}{ Conventional Concrete } \\
\cline { 2 - 5 } & $\begin{array}{c}\text { Compressive } \\
\text { Strength (MPa) }\end{array}$ & $\begin{array}{c}\text { Modulus of } \\
\text { Elasticity (GPa) }\end{array}$ & $\begin{array}{c}\text { Compressive } \\
\text { Strength (MPa) }\end{array}$ & $\begin{array}{c}\text { Modulus of } \\
\text { Elasticity (GPa) }\end{array}$ \\
\hline Average & 17.65 & 13.41 & 28.75 & 29.01 \\
\hline $\begin{array}{c}\text { Standard } \\
\text { Deviation }\end{array}$ & 1.81 & 1.81 & 1.31 & 1.74 \\
\hline $\begin{array}{c}\text { Coefficient of } \\
\text { Variation }(\%)\end{array}$ & 10.28 & 13.52 & 4.57 & 6.00 \\
\hline
\end{tabular}

As can be seen, the value achieved by the developed RCA-based concrete fits within the range defined by the literature for pervious concretes. However, this value represents approximately $60 \%$ of the value obtained by conventional concrete, even with similar cement content. This fact is mainly related to the difference between the aggregates used and the different moulding and compaction techniques used that make the pervious concrete structure more porous, consequently decreasing its compressive strength.

Even so, the value meets the range of 10-13 MPa for projected compressive strength that is preferred for parking lots, stone protection, drainage pavement, and porous concrete precast products $[3,76]$. In Figure 12, the results obtained in this study (darker) are compared to the ones found in the literature for pervious concretes with recycled aggregates.

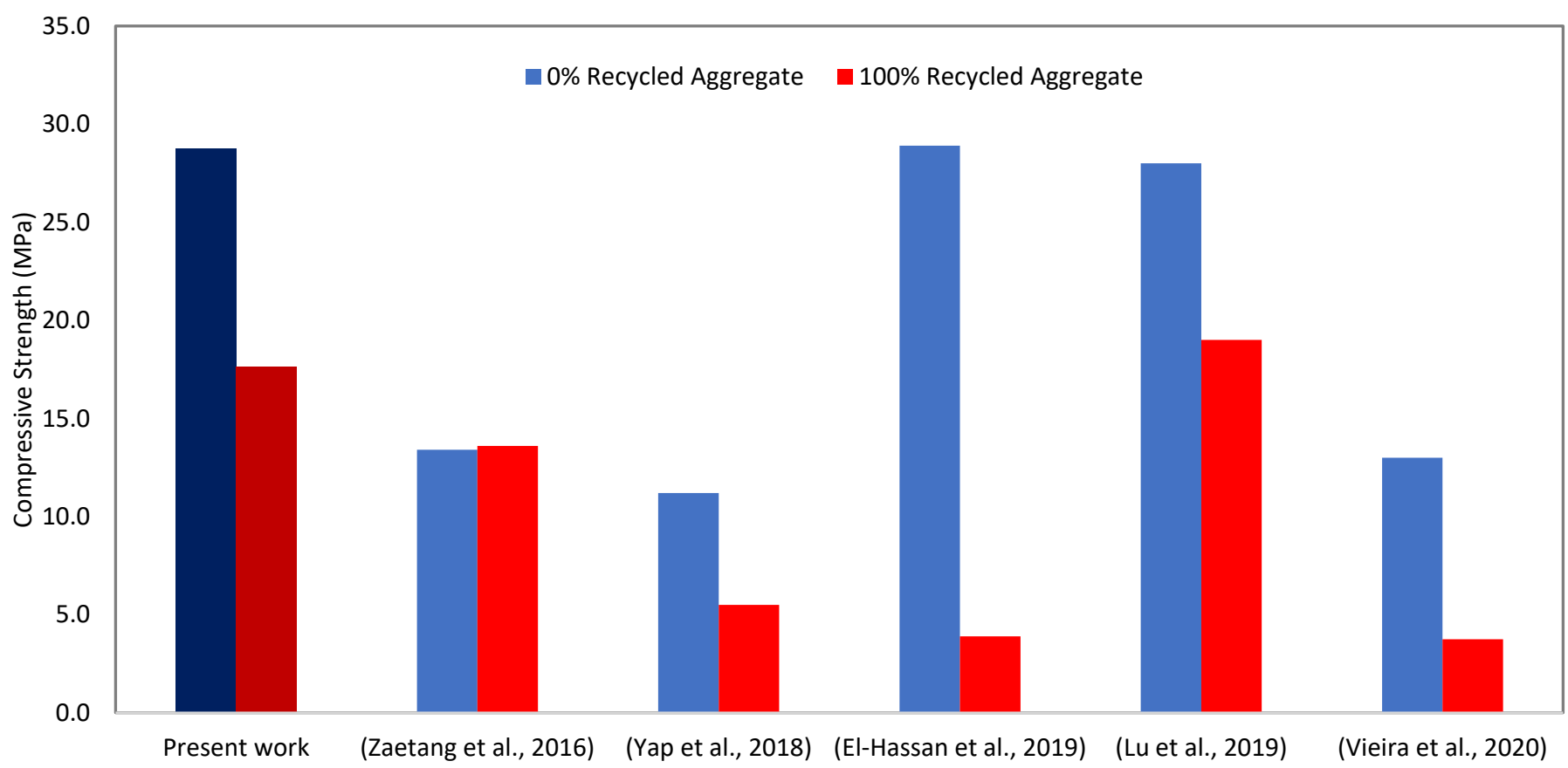

Figure 12. Comparison between the compressive strength values obtained in this study and in other research.

It is possible to identify that the RCA-based pervious concrete developed has a compressive strength higher than the one of other studies that used $100 \%$ recycled aggregates, 
except for the pervious concrete with the addition of silica fume, produced by Lu et al. [14]. The lowest indexes presented are associated with CDW residues not exclusively from concrete, which justifies the choice for RCAs in this study. As for pervious concrete with natural aggregates, those that had a compressive strength closest to the conventional concrete presented in this study were that of El-Hassan et al. [10], designed with lower void index and higher cement content, and, again, that of Lu et al. [14], which had silica fume in the composition.

\subsection{Modulus of Elasticity}

Because it is a mechanical wave, ultrasound propagates better in a denser environment. Therefore, the greater the concrete's porosity, the lower its dynamic modulus of elasticity [9]. As presented in Table 10, the pervious concrete's elasticity modulus is $54 \%$ lower than the one obtained by the conventional concrete, which is close to the limit of $28 \mathrm{GPa}$ defined by Cook, Goodspeed, and Vanicar [77]. This is due to the porous composition of the pervious concrete, which has a more significant volume of voids that is also enhanced by incorporating RCAs.

The value obtained for pervious concrete is similar to the value obtained by Yap et al. [3] (Figure 13), although they obtained a higher modulus of elasticity for the RCA-based pervious concrete compared to the one with natural aggregates. According to the authors, this finding does not represent the expected result, because when RCA is incorporated into the concrete, the composite bond between the cement paste and the aggregate is reduced.

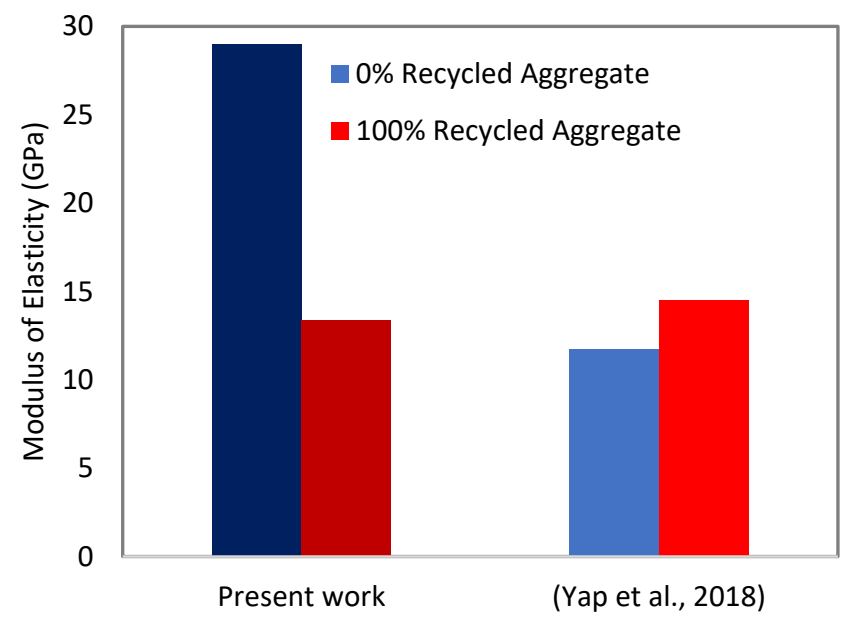

Figure 13. Comparison between the modulus of elasticity values obtained in this study and in the literature.

\subsection{Flexural Strength}

The Brazilian standard NBR 16416 [42] specifies a flexural strength in pervious concrete slabs moulded "in situ" greater than $1 \mathrm{MPa}$ for pedestrian traffic, while for light traffic, the minimum is $2 \mathrm{MPa}$. All values obtained for the pervious concrete prisms studied exceed these limits (average: $2.21 \mathrm{MPa}$; standard deviation: $0.05 \mathrm{MPa}$; variation coefficient: $2.40 \%$ ), indicating that it is an ideal material for both purposes.

Figure 14 presents the flexural strength values obtained together with the values found by reference studies that performed the same test. As for the compressive strength, it is possible to note that the values achieved by pervious concretes with recycled aggregates are lower than those of concretes with natural aggregates. This is probably due to the lower abrasion resistance and lower density of the recycled aggregates, which causes an increase in the volume of internal voids in the composite, making it more fragile to mechanical stresses [52]. The fact that can justify the higher flexural strength obtained in the study of Zaetang et al. [4] is the use of plasticiser additive, which contributes to improving the workability characteristics of concrete as it facilitates water dispersion considering the hydration of the paste. 


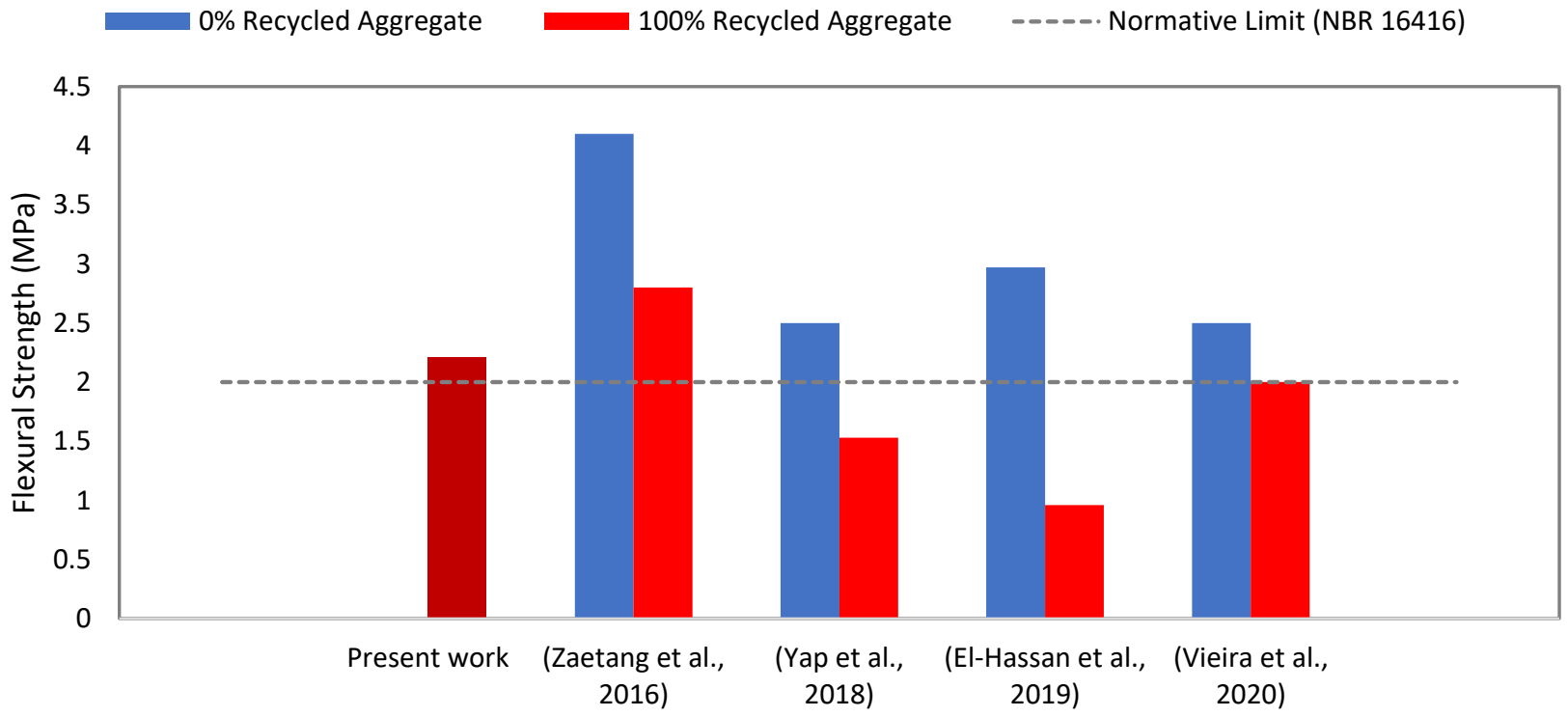

Figure 14. Comparison between the flexural strength values obtained in this study and in the literature.

\subsection{Permeability Coefficient}

The ability to allow water to seep through its pore structure makes pervious concrete stand out among other concrete types [3]. Thus, water permeability is an important property to evaluate its performance [78]. NBR 16416 [42] specifies the permeability value of $0.1 \mathrm{~cm} / \mathrm{s}$ as the minimum criterion that the pavement must present in the first days after its execution. ACI 522R [27], in turn, establishes a minimum value of $0.14 \mathrm{~cm} / \mathrm{s}$ for the permeability coefficient in pervious concretes.

Figure 15 shows the permeability coefficients obtained for the $6 \mathrm{~cm}$ and $8 \mathrm{~cm}$ plates compared to the values found in the reference studies. As can be seen, although they present high coefficients of variation $(20.77 \%$ and $20.10 \%)$, both samples investigated showed permeability values above the minimum specified by normalisation and within the range of values described in the literature (average of $1.20 \mathrm{~cm} / \mathrm{s}$ for $6 \mathrm{~cm}$ thick plates and an average of $1.76 \mathrm{~cm} / \mathrm{s}$ for $8 \mathrm{~cm}$ plates).

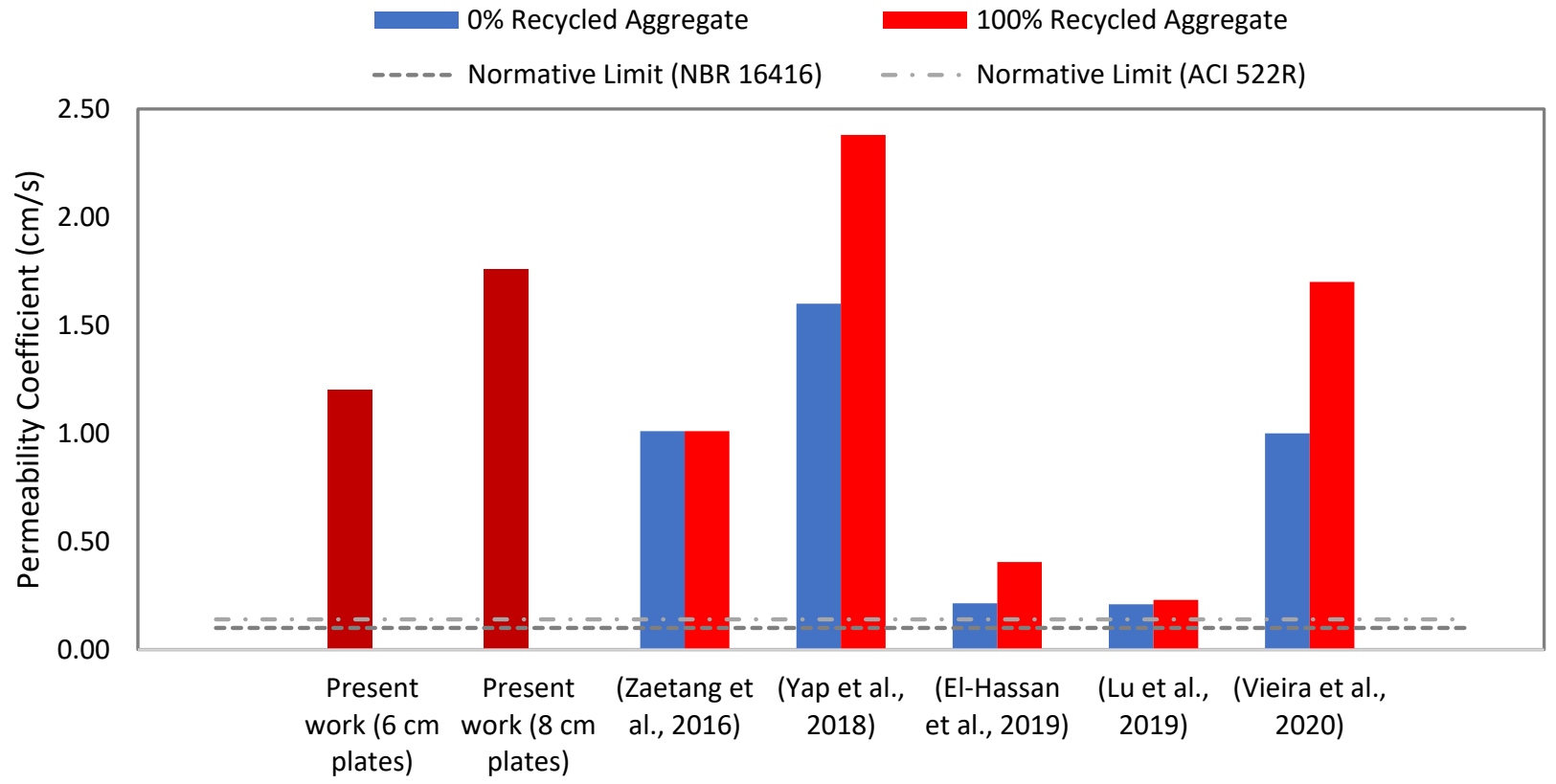

Figure 15. Comparison between the permeability coefficient values obtained in this study and in the literature. 
It is worth mentioning that El-Hassan et al. [10] reached permeability values much lower than the ones of the other studies. This is due to the lower design porosity adopted by the authors. Although above the normative requirements, the lower indexes are associated with pervious concretes with higher mechanical strength values [14]. This indicates that the same characteristics capable of affecting its resistance to stresses (porosity and structure with interconnected voids) are responsible for making the concrete more permeable. In general, it is difficult to simultaneously optimise mechanical and durability properties and infiltration, since the good performance of pervious concrete is governed by porosity [33]. This fact sums up the most significant research challenge surrounding this material: to develop pervious concretes without neglecting their mechanical capacity.

\subsection{Pilot-Scale Case Study}

The results of the tests of fresh density, flexural strength, and permeability coefficient performed for the parking space lined with pervious concrete are shown in Table 11.

Table 11. Results of fresh density, flexural strength, and permeability coefficient obtained in the pilot-scale case study.

\begin{tabular}{cccc}
\hline Data & $\begin{array}{c}\text { Fresh Density } \\
\left(\mathbf{k g} / \mathbf{m}^{\mathbf{3}} \mathbf{)}\right.\end{array}$ & $\begin{array}{c}\text { Flexural Strength } \\
\mathbf{( M P a )}\end{array}$ & $\begin{array}{c}\text { Permeability } \\
\text { Coefficient } \mathbf{( c m} / \mathbf{s})\end{array}$ \\
\hline Average & 1675.9 & 1.85 & 2.74 \\
Standard Deviation & 27.78 & 0.23 & 0.46 \\
Coefficient of Variation $(\%)$ & 1.66 & 12.15 & 16.64 \\
\hline
\end{tabular}

As in the laboratory tests, the fresh density results found for the case study are within the normative limits. It can also be noted that the permeability coefficient tests performed in the parking space demonstrated the draining potential of the pervious concrete developed: the results obtained were even higher than the values found in the laboratory.

However, it is noted that the case study presented a mechanical resistance lower than the values obtained in the laboratory. This can be justified by the RCAs' natural variability; their strength may vary according to the condition and function of the original concrete. Although the value is slightly below the limit for light traffic, this material is acceptable for pedestrian trails and walkways since the Brazilian standard limits the flexural strength for pedestrian traffic with pervious concrete coating moulded "in situ" to $1.00 \mathrm{MPa}$.

Considering the hydraulic capacity well above the limit of the developed material, an alternative to increasing the mechanical performance of pervious concrete is presented by Ibrahim et al. [28]. It consists in incorporating recycled fine aggregates into the concrete mixture, which, due to the packaging phenomenon, would improve the thickness of the paste and the interlock between the aggregate and the concrete, thus reducing the variation in the porosity of the material. This would result in increased flexural and compressive strength but would produce a less porous mesh, reducing the permeability coefficient.

\subsection{Environmental Performance Assessment}

Tables 12 and 13 present the values obtained from the quantification of the environmental impact categories for the different concrete formulations in scenarios 1 and 2, respectively.

Analysing the results, in both scenarios, it is possible to verify that the concretes that use a more considerable amount of cement in their composition have the highest values of environmental impact. Additionally, the mixtures that use Type I cement present higher values for ADP_FF and GWP 100 because they have a greater amount of clinker in their composition. The higher greenhouse gas emissions (GWP) are related to the amount of cement, resulting from clinker production $[79,80]$. 
Table 12. Values obtained for the different environmental impact indicators for each concrete formulation in scenario 1 .

\begin{tabular}{ccccccc}
\hline Concrete & GWP 100 & ODP & AP & EP & POCP & ADP_FF \\
\hline CC-Ref-R0 & $2.39 \times 10^{2}$ & $5.70 \times 10^{-6}$ & $7.37 \times 10^{-1}$ & $1.37 \times 10^{-1}$ & $4.78 \times 10^{-2}$ & $1.30 \times 10^{3}$ \\
PC-R100 & $3.30 \times 10^{2}$ & $8.64 \times 10^{-6}$ & $8.45 \times 10^{-1}$ & $1.58 \times 10^{-1}$ & $4.10 \times 10^{-2}$ & $1.33 \times 10^{3}$ \\
Z-R0 & $3.07 \times 10^{2}$ & $1.12 \times 10^{-5}$ & $7.02 \times 10^{-1}$ & $1.68 \times 10^{-1}$ & $2.96 \times 10^{-2}$ & $1.42 \times 10^{3}$ \\
Z-R100 & $3.41 \times 10^{2}$ & $1.78 \times 10^{-5}$ & $8.74 \times 10^{-1}$ & $2.07 \times 10^{-1}$ & $3.48 \times 10^{-2}$ & $1.98 \times 10^{3}$ \\
Y-R0 & $3.42 \times 10^{2}$ & $1.18 \times 10^{-5}$ & $7.59 \times 10^{-1}$ & $1.81 \times 10^{-1}$ & $3.13 \times 10^{-2}$ & $1.49 \times 10^{3}$ \\
Y-R100 & $3.79 \times 10^{2}$ & $1.88 \times 10^{-5}$ & $9.43 \times 10^{-1}$ & $2.23 \times 10^{-1}$ & $3.70 \times 10^{-2}$ & $2.09 \times 10^{3}$ \\
E-R0 & $5.47 \times 10^{2}$ & $1.82 \times 10^{-5}$ & 1.19 & $2.80 \times 10^{-1}$ & $4.83 \times 10^{-2}$ & $2.34 \times 10^{3}$ \\
E-R100 & $5.05 \times 10^{2}$ & $2.19 \times 10^{-5}$ & 1.19 & $2.80 \times 10^{-1}$ & $4.68 \times 10^{-2}$ & $2.55 \times 10^{3}$ \\
L-R0 & $2.66 \times 10^{2}$ & $1.00 \times 10^{-5}$ & $6.13 \times 10^{-1}$ & $1.48 \times 10^{-1}$ & $2.56 \times 10^{-2}$ & $1.23 \times 10^{3}$ \\
L-R100 & $3.02 \times 10^{2}$ & $1.70 \times 10^{-5}$ & $7.93 \times 10^{-1}$ & $1.89 \times 10^{-1}$ & $3.11 \times 10^{-2}$ & $1.82 \times 10^{3}$ \\
V-R0 & $4.98 \times 10^{2}$ & $5.13 \times 10^{-6}$ & 1.15 & $2.02 \times 10^{-1}$ & $6.00 \times 10^{-2}$ & $1.42 \times 10^{3}$ \\
V-R100 & $4.75 \times 10^{2}$ & $1.27 \times 10^{-5}$ & 1.22 & $2.25 \times 10^{-1}$ & $5.87 \times 10^{-2}$ & $1.94 \times 10^{3}$ \\
\hline
\end{tabular}

Table 13. Values obtained for the different environmental impact indicators for each concrete formulation in scenario 2 .

\begin{tabular}{ccccccc}
\hline Concrete & GWP 100 & ODP & AP & EP & POCP & ADP_FF \\
\hline CC-Ref-R0 & $2.39 \times 10^{2}$ & $5.70 \times 10^{-6}$ & $7.37 \times 10^{-1}$ & $1.37 \times 10^{-1}$ & $4.78 \times 10^{-2}$ & $1.30 \times 10^{3}$ \\
PC-R100 & $2.99 \times 10^{2}$ & $2.80 \times 10^{-6}$ & $6.83 \times 10^{-1}$ & $1.20 \times 10^{-1}$ & $3.51 \times 10^{-2}$ & $8.28 \times 10^{2}$ \\
Z-R0 & $3.07 \times 10^{2}$ & $1.12 \times 10^{-5}$ & $7.02 \times 10^{-1}$ & $1.68 \times 10^{-1}$ & $2.96 \times 10^{-2}$ & $1.42 \times 10^{3}$ \\
Z-R100 & $3.03 \times 10^{2}$ & $1.07 \times 10^{-5}$ & $6.76 \times 10^{-1}$ & $1.61 \times 10^{-1}$ & $2.76 \times 10^{-2}$ & $1.37 \times 10^{3}$ \\
Y-R0 & $3.42 \times 10^{2}$ & $1.18 \times 10^{-5}$ & $7.59 \times 10^{-1}$ & $1.81 \times 10^{-1}$ & $3.13 \times 10^{-2}$ & $1.49 \times 10^{3}$ \\
Y-R100 & $3.39 \times 10^{2}$ & $1.14 \times 10^{-5}$ & $7.38 \times 10^{-1}$ & $1.75 \times 10^{-1}$ & $2.96 \times 10^{-2}$ & $1.46 \times 10^{3}$ \\
E-R0 & $5.47 \times 10^{2}$ & $1.82 \times 10^{-5}$ & 1.19 & $2.80 \times 10^{-1}$ & $4.83 \times 10^{-2}$ & $2.34 \times 10^{3}$ \\
E-R100 & $4.69 \times 10^{2}$ & $1.54 \times 10^{-5}$ & 1.01 & $2.37 \times 10^{-1}$ & $4.02 \times 10^{-2}$ & $1.98 \times 10^{3}$ \\
L-R0 & $2.66 \times 10^{2}$ & $1.00 \times 10^{-5}$ & $6.13 \times 10^{-1}$ & $1.48 \times 10^{-1}$ & $2.56 \times 10^{-2}$ & $1.23 \times 10^{3}$ \\
L-R100 & $2.62 \times 10^{2}$ & $9.49 \times 10^{-6}$ & $5.86 \times 10^{-1}$ & $1.40 \times 10^{-1}$ & $2.35 \times 10^{-2}$ & $1.17 \times 10^{3}$ \\
V-R0 & $4.98 \times 10^{2}$ & $5.13 \times 10^{-6}$ & 1.15 & $2.02 \times 10^{-1}$ & $6.00 \times 10^{-2}$ & $1.42 \times 10^{3}$ \\
V-R100 & $4.28 \times 10^{2}$ & $3.87 \times 10^{-6}$ & $9.71 \times 10^{-1}$ & $1.68 \times 10^{-1}$ & $4.98 \times 10^{-2}$ & $1.18 \times 10^{3}$ \\
\hline
\end{tabular}

The higher cement consumption observed in the work of Yap et al. [3] compared to the pervious concrete developed in this study may be associated with the use of aggregates with lower granulometry. The larger specific surface of smaller aggregates may require a higher binder content needed to surround the aggregated particles. This ends up in a material with a higher potential environmental impact.

Table 14 presents the normalisation of the values obtained for each environmental impact category in scenarios 1 and 2. The normalisation of the values allows a better understanding of the environmental performance of each concrete comparatively.

Table 14. Normalised values of the studied environmental impact categories.

\begin{tabular}{ccccccccccccc}
\hline Concrete & \multicolumn{9}{c}{ Scenario 1 } & \multicolumn{5}{c}{ Scenario 2 } \\
\hline & GWP & ODP & AP & EP & POCP & ADP_FF & GWP & ODP & AP & EP & POCP & ADP_FF \\
\hline CC-Ref-R0 & 1.00 & 0.97 & 0.79 & 1.00 & 0.35 & 0.95 & 1.00 & 0.81 & 0.75 & 0.90 & 0.33 & 0.69 \\
PC-R100 & 0.70 & 0.79 & 0.62 & 0.85 & 0.55 & 0.92 & 0.81 & 1.00 & 0.84 & 1.00 & 0.68 & 1.00 \\
Z-R0 & 0.78 & 0.64 & 0.85 & 0.78 & 0.88 & 0.85 & 0.78 & 0.45 & 0.81 & 0.70 & 0.83 & 0.61 \\
Z-R100 & 0.67 & 0.24 & 0.57 & 0.51 & 0.73 & 0.43 & 0.79 & 0.49 & 0.85 & 0.75 & 0.89 & 0.64 \\
Y-R0 & 0.66 & 0.60 & 0.76 & 0.69 & 0.84 & 0.80 & 0.66 & 0.42 & 0.71 & 0.62 & 0.79 & 0.56 \\
Y-R100 & 0.55 & 0.19 & 0.45 & 0.40 & 0.67 & 0.35 & 0.67 & 0.44 & 0.75 & 0.66 & 0.83 & 0.58 \\
E-R0 & 0.00 & 0.22 & 0.05 & 0.00 & 0.34 & 0.16 & 0.00 & 0.00 & 0.00 & 0.00 & 0.32 & 0.00 \\
E-R100 & 0.14 & 0.00 & 0.04 & 0.00 & 0.38 & 0.00 & 0.25 & 0.18 & 0.30 & 0.27 & 0.54 & 0.23 \\
L-R0 & 0.91 & 0.71 & 1.00 & 0.92 & 1.00 & 1.00 & 0.91 & 0.53 & 0.96 & 0.83 & 0.94 & 0.74 \\
L-R100 & 0.79 & 0.29 & 0.70 & 0.64 & 0.84 & 0.55 & 0.92 & 0.56 & 1.00 & 0.88 & 1.00 & 0.77 \\
V-R0 & 0.16 & 1.00 & 0.11 & 0.54 & 0.00 & 0.85 & 0.16 & 0.85 & 0.06 & 0.49 & 0.00 & 0.61 \\
V-R100 & 0.23 & 0.55 & 0.00 & 0.38 & 0.04 & 0.46 & 0.39 & 0.93 & 0.36 & 0.70 & 0.28 & 0.77 \\
\hline
\end{tabular}


In general, in scenario 1, where the recycled aggregate transportation between the waste treatment plant and the concrete company is considered, concretes with recycled aggregates from each study show a worse environmental performance compared to those with natural aggregates. In scenario 2, this situation is reversed. This reflects the relevant contribution of transport to the embodied environmental impact of construction materials.

Figure 16 compares the GWP of the gravel with that of the RCA, considering the cradle-to-gate plus transportation GWP emissions. The method used is the one proposed by Zulcão et al. [81], focused on the GWP impact category. The gravel's transport distance is kept constant $(16.6 \mathrm{~km})$ in this study for the various concrete compositions. Therefore, the emissions related to transportation from the quarry to the concrete plant do not vary $\left(3.02 \times 10^{2} \mathrm{kgCO}_{2} \mathrm{eq}\right)$. The RCA production process has a lower potential environmental impact than the one resulting from the production of natural aggregates. However, if RCAs' transportation distance is higher than that of gravel, the cradle-to-gate plus transportation potential environmental impacts can also be worse. In that case, using RCAs instead of natural aggregates could be worse from the environmental point of view. Then, in this context, RCA has lower potential environmental impacts than gravel for transport distances below $33 \mathrm{~km}$. This conclusion is analogous to the one of similar studies, such as Zaetang et al. [4] and Lu et al. [14], which maintain the same amount of aggregates in their compositions with only recycled or natural aggregates.

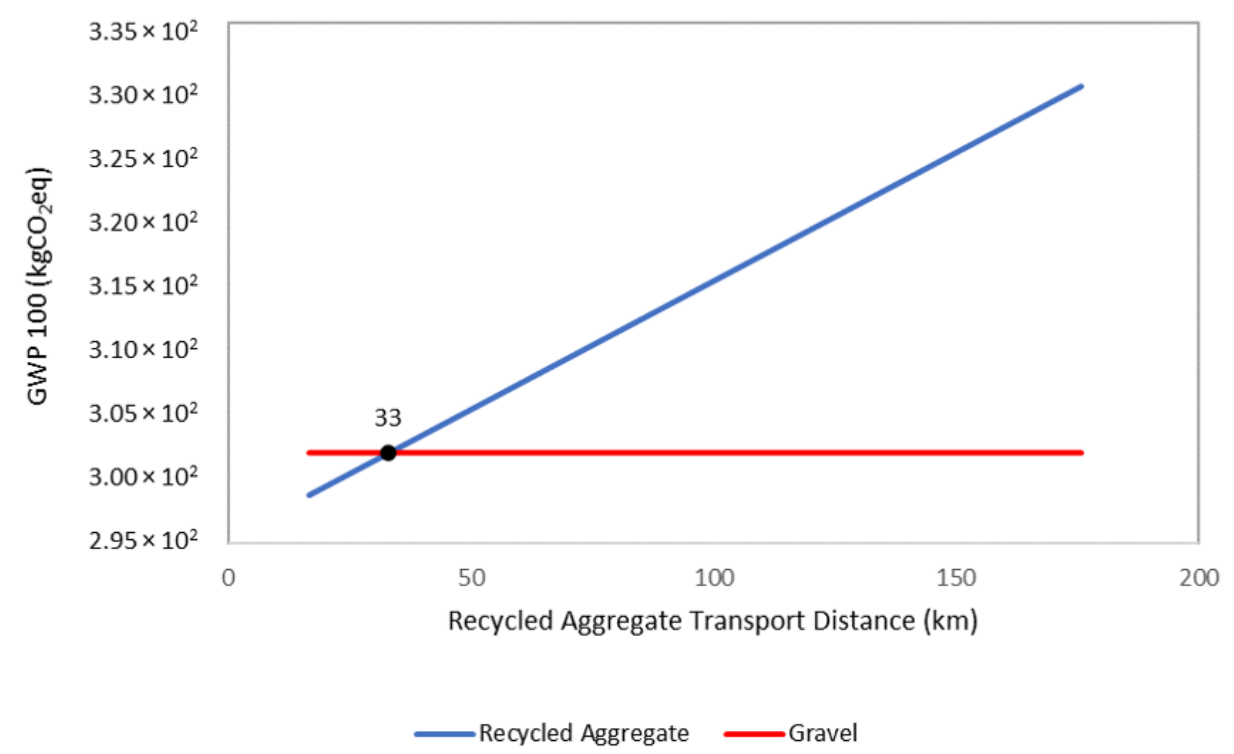

Figure 16. Correlation between global warming (GWP) emissions and the transport distance of the recycled aggregates.

When bringing in the context of the materials developed in this work, it is observed that conventional concrete achieves better environmental performance in all indicators in scenario 1 . In scenario 2, due to the shortening of the recycled aggregate transport distance, the RCA-based pervious concrete obtains better results for all indicators, except for GWP. This exception probably results from the fact that the amount of $\mathrm{CO}_{2}(0.906 \mathrm{~g} / \mathrm{kg})$ emitted from the production of $1 \mathrm{~kg}$ of $\mathrm{CP} \mathrm{V}$ cement is almost double the $\mathrm{CO}_{2}$ emissions associated with the production of CP III cement $(587 \mathrm{~g} / \mathrm{kg})$ [65].

Tables 15 and 16 show the sustainable profiles and the overall environmental performance of each concrete formulation for scenarios 1 and 2, respectively. In the profiles, the shaded area represents the performance of each studied concrete. At the level of each impact category, the best concrete has a value closer to one. 
Table 15. Normalised values that describe the sustainability profile of scenario 1.

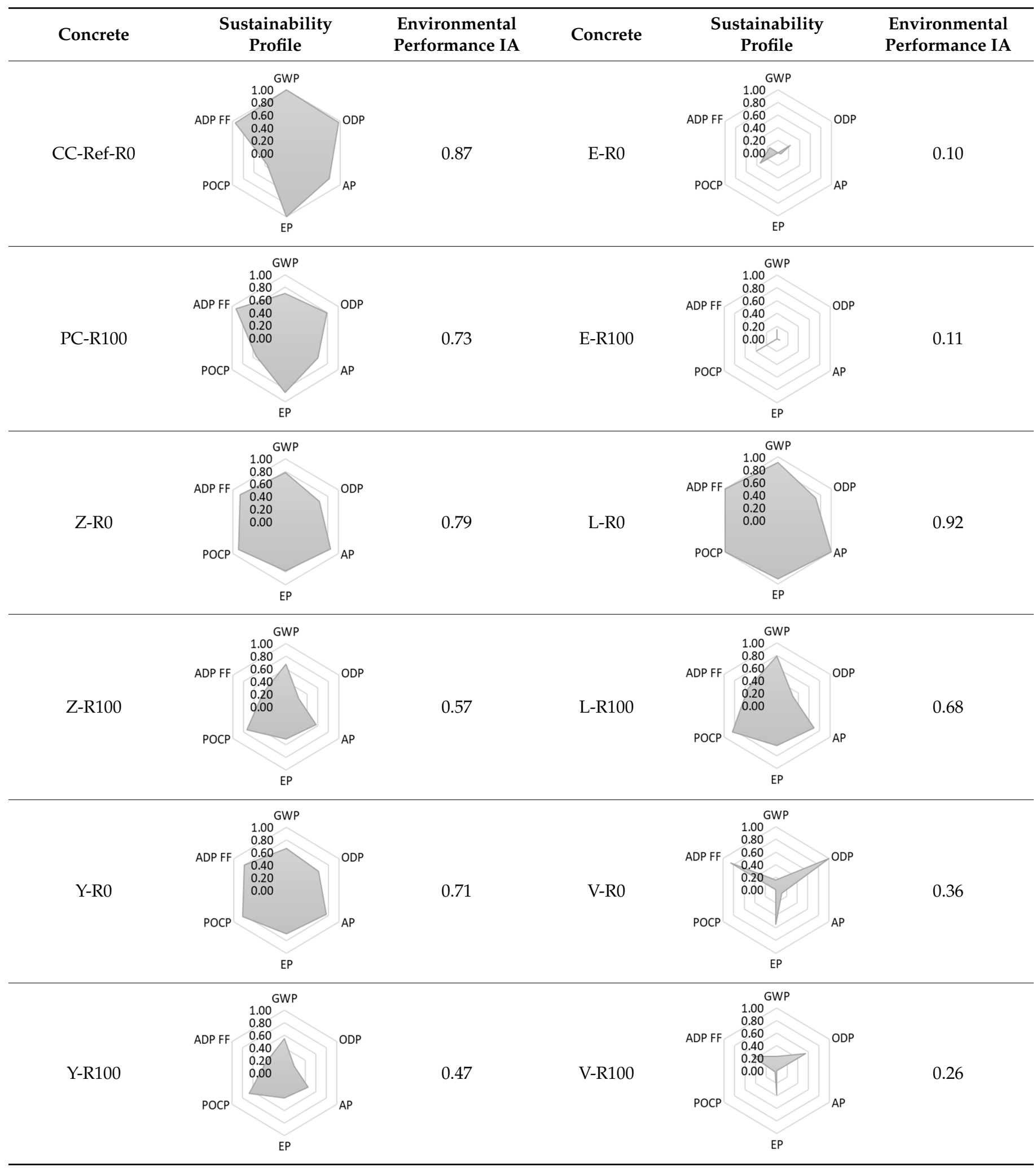


Table 16. Normalised values that describe the sustainability profile of scenario 2.

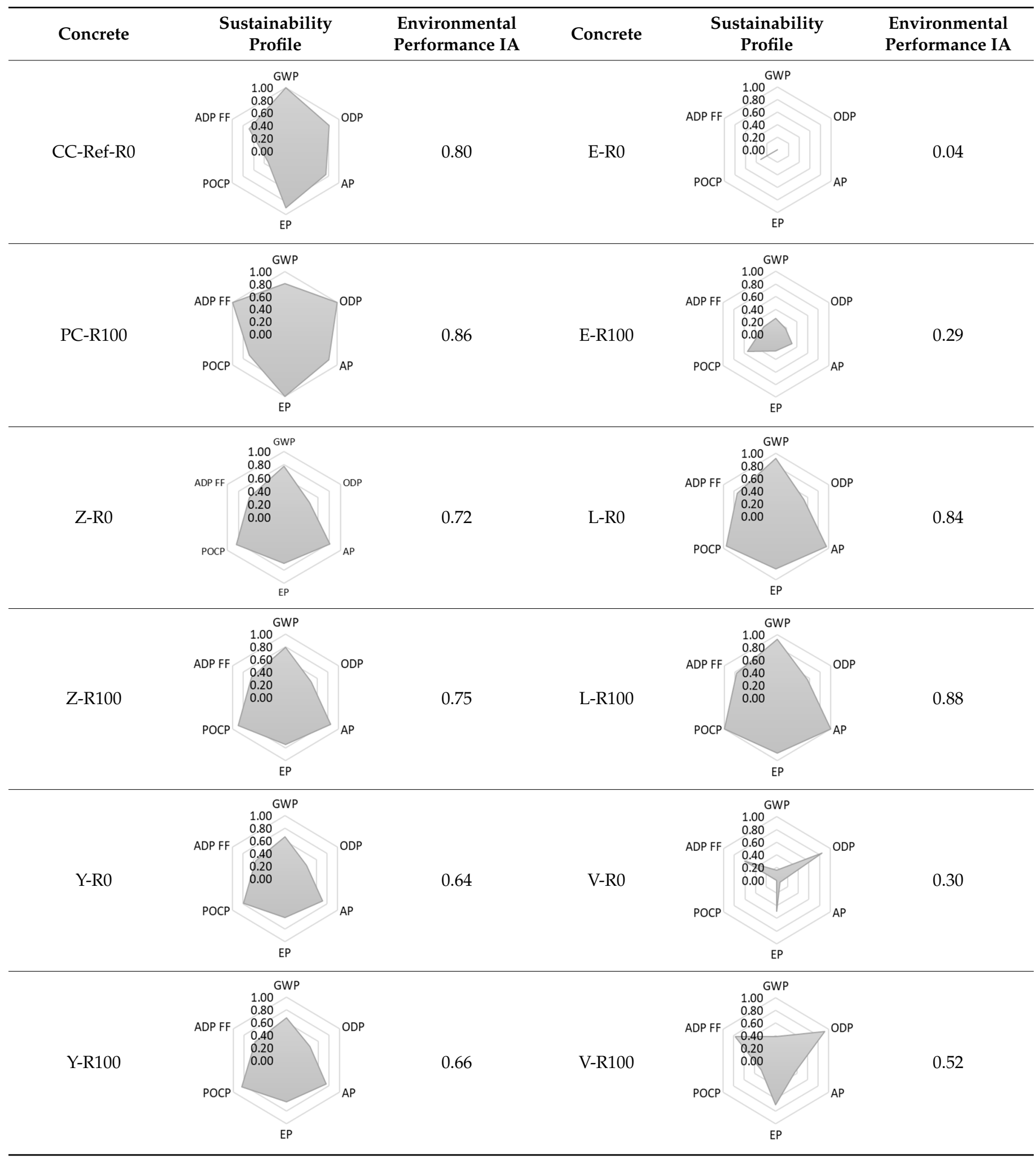

It is a fact that the pervious concrete developed in this study (PC-R100) and the RCAbased pervious concrete produced by Zaetang et al. [4] (Z-R100) present similar materials. Comparing the environmental performances, it is observed that the PC-R100 obtains better results in most indicators. This difference may be explained by the use of a different type of cement and plasticiser additives in the reference study. The increase in the amount of 
superplasticiser leads to an increase in the potential environmental impacts [29]. According to Heede and Belie [82], the amount of $\mathrm{CO}_{2}$ emitted from the production of $1 \mathrm{~kg}$ of superplasticiser is close to that from the cement production.

Finally, it is worth analysing the performance of the RCA-based pervious concrete from Lu et al. [14], in which silica fume was incorporated. In scenario 1, its performance was lower than that of the pervious concrete in the present study, even with lower cement content. Since it has a greater amount of RCAs, the influence of the transport distance of the recycled aggregate increases proportionally. As for scenario 2, where the environmental impact of the recycled aggregate is less relevant, the smaller amount of cement made possible by incorporating silica fume makes it more eco-friendly.

This fact is corroborated by comparing the two concretes with silica fume: even presenting the same amount of aggregate in scenario 1, the L-OR, made up of natural aggregates, is better at the environmental level; for scenario 2, where the transport distances are the same, the L-100R, with $100 \%$ RCA, had the lower environmental impact.

In general, identifying the factors that influence environmental performance and the possibility of producing a functional and environmentally optimised material represents a solution for the sustainability of the concrete industry.

\section{Conclusions}

This study investigated the effect of replacing $100 \%$ of natural aggregates with recycled concrete aggregates (RCAs) in the production of pervious concrete. For this, the mechanical and hydraulic properties and environmental performance of the product developed were studied. Based on the results achieved, it is possible to draw some relevant conclusions:

- The results obtained in the permeability coefficient test demonstrated the excellent draining potential of the elaborated composite. All the plates tested had coefficients above the normative limit, equivalent to $0.1 \mathrm{~cm} / \mathrm{s}$.

- The high levels of hydraulic conductivity are associated with the greater void index of the pervious concrete, which is inversely proportional to its hardened density. However, these characteristics negatively affect the mechanical strength of the material.

- The RCA-based pervious concrete developed has great functional potential. The mechanical tests performed in the laboratory obtained values compatible with the literature and above the minimum functional requirements. However, as the mechanical strength of concrete is intrinsically dependent on the aggregate used, it is recommended to use RCA from concretes that had a structural function in the previous life cycle.

- Due to the inherent variability of recycled aggregates, it is crucial to develop classification procedures based on some physical characteristics, such as density, water absorption, or abrasion resistance, to avoid further dispersion of performance properties. In general, it should be considered that the greater the strength of the concrete is that gave rise to the recycled aggregate, the greater the resistance will be of the final product.

- Regarding the case study, it was found that the permeability of the pavement is similar to the one measured in the laboratory. Although the flexural strength in the parking space did not meet the limits of the parameter for vehicle traffic, the results were favourable for pedestrian traffic. This discrepancy between the laboratory results and "in situ" results can be attributed to the different strengths and conditions of the concrete that gave rise to the recycled aggregate.

- Therefore, it is important to establish a way to increase the mechanical strength of pervious concrete developed with RCAs. In this scenario, it is possible to consider incorporating a certain amount of fine aggregates to the pervious concrete mixture to increase its mechanical resistance, without neglecting its hydraulic capacity and environmental performance.

- With respect to the microstructure of RCA-based pervious concrete, it was possible to identify that the interface between the recycled aggregate and the old mortar 
becomes the most vulnerable phase of the concrete. The bonded mortar's carbonation demonstrates poor aggregate-paste adhesion, and the TLM and XRD tests suggested that the material rupture occurs in the aggregate itself.

- RCA represents a positive contribution to the environmental performance of pervious concrete when compared to conventional concrete and pervious concrete with natural aggregates from other studies. However, one must pay attention to the transport distance of the recycled aggregate between the concrete plant and the waste treatment plant where the aggregate will be received.

- It is worth mentioning the sustainability potential of incorporating silica fume. On analysing the mixtures taken from the literature, those that presented the best functional and environmental performances are the ones composed of this material.

- Although this study focuses on characterising materials produced in Brazil using national standards, the used approach is based on commonly accepted international standards such as ACI and ASTM standards. Therefore, it is expected that using the same experimental procedures in other regions will result in similar conclusions. Nevertheless, regarding the LCA analysis, it is strongly recommended to use regional life cycle inventory data. Additionally, it is essential to notice that the characteristics of pervious concretes with recycled aggregates could be different in other regions, since it is known that the characteristics of RCAs are strongly dependent on the materials used for the construction from which they come.

In general, the present study showed the great potential of using recycled concrete aggregates to produce pervious concrete. The economic and environmental benefits associated with the application of pervious concrete coatings on urban pavements can be enhanced using RCAs in their composition. Several aspects are challenging the path for more sustainable construction, such as reducing CDW and the consumption of natural resources. Therefore, it is natural to consider new studies on materials of this kind, including a more in-depth analysis of their performance and their relationship with the reduction in urban run-off. Besides, it is important to evaluate how it can contribute to other sustainability dimensions (social and economy) to obtain a more comprehensive picture of the sustainability potential of RCA-based pervious concrete.

Author Contributions: Conceptualization, A.C.P.J., T.M.O., A.E.P., F.M.B., E.R.T. and R.M.; methodology, A.C.P.J., C.J., T.M.O., E.R.T. and R.M.; validation, T.M.O., A.E.P., E.R.T. and R.M.; formal analysis, T.M.O., E.R.T. and R.M.; investigation, A.C.P.J., C.J., T.M.O., A.E.P. and F.M.B.; resources, T.M.O., A.E.P., F.M.B. and R.M.; data curation, A.C.P.J., C.J. and E.R.T.; writing—original draft preparation, A.C.P.J.; writing-review and editing, A.C.P.J., C.J., T.M.O., E.R.T. and R.M.; supervision, T.M.O., E.R.T. and R.M.; project administration, T.M.O. and R.M. All authors have read and agreed to the published version of the manuscript.

Funding: This research received no external funding.

Institutional Review Board Statement: Not applicable.

Informed Consent Statement: Not applicable.

Data Availability Statement: The data presented in this study are available on request from the corresponding author.

Acknowledgments: The authors acknowledge the support of Fundação de Amparo à Pesquisa de Minas Gerais (FAPEMIG); Conselho Nacional de Desenvolvimento Científico e Tecnológico (CNPq); Coordenação de Aperfeiçoamento de Pessoal de Nível Superior (CAPES); Pró-Reitoria de Pós-Graduação e Pesquisa da Universidade Federal de Juiz de Fora (PROPP/UFJF); Pró-Reitoria de Infraestrutura da Universidade Federal de Juiz de Fora (PROINFRA/UFJF); Petra Agregados; and Associação Brasileira de Cimento Portland (ABCP).

Conflicts of Interest: The authors declare no conflict of interest. 


\section{References}

1. Rodríguez, C.; Parra, C.; Casado, G.; Miñano, I.; Albaladejo, F.; Benito, F.; Sánchez, I. The incorporation of construction and demolition wastes as recycled mixed aggregates in non-structural concrete precast pieces. J. Clean. Prod. 2016, 127, 152-161. [CrossRef]

2. Aliabdo, A.A.; Elmoaty, A.E.M.A.; Fawzy, A.M. Experimental investigation on permeability indices and strength of modified pervious concrete with recycled concrete aggregate. Constr. Build. Mater. 2018, 193, 105-127. [CrossRef]

3. Yap, S.P.; Chen, P.Z.C.; Goh, Y.; Ibrahim, H.A.; Mo, K.H.; Yuen, C.W. Characterization of pervious concrete with blended natural aggregate and recycled concrete aggregates. J. Clean. Prod. 2018, 181, 155-165. [CrossRef]

4. Zaetang, Y.; Sata, V.; Wongsa, A.; Chindaprasirt, P. Properties of pervious concrete containing recycled concrete block aggregate and recycled concrete aggregate. Constr. Build. Mater. 2016, 111, 15-21. [CrossRef]

5. Bravo, M.; de Brito, J.; Pontes, J.; Evangelista, L. Mechanical performance of concrete made with aggregates from construction and demolition waste recycling plants. J. Clean. Prod. 2015, 99, 59-74. [CrossRef]

6. Sadati, S.; Arezoumandi, M.; Khayat, K.H.; Volz, J.S. Shear performance of reinforced concrete beams incorporating recycled concrete aggregate and high-volume fly ash. J. Clean. Prod. 2016, 115, 284-293. [CrossRef]

7. Zhang, Z.; Zhang, Y.; Yan, C.; Liu, Y. Influence of crushing index on properties of recycled aggregates pervious concrete. Constr. Build. Mater. 2017, 135, 112-118. [CrossRef]

8. Ibrahim, H.A.; Razak, H.A. Effect of palm oil clinker incorporation on properties of pervious concrete. Constr. Build. Mater. 2016, 115, 70-77. [CrossRef]

9. Tam, V.W.; Butera, A.; Le, K.N. Carbon-conditioned recycled aggregate in concrete production. J. Clean. Prod. 2016, 133, 672-680. [CrossRef]

10. El-Hassan, H.; Kianmehr, P.; Zouaoui, S. Properties of pervious concrete incorporating recycled concrete aggregates and slag. Constr. Build. Mater. 2019, 212, 164-175. [CrossRef]

11. Guo, Z.; Tu, A.; Chen, C.; Lehman, D.E. Mechanical properties, durability, and life-cycle assessment of concrete building blocks incorporating recycled concrete aggregates. J. Clean. Prod. 2018, 199, 136-149. [CrossRef]

12. Çakır, Ö. Experimental analysis of properties of recycled coarse aggregate (RCA) concrete with mineral additives. Constr. Build. Mater. 2014, 68, 17-25. [CrossRef]

13. Dimitriou, G.; Savva, P.; Petrou, M.F. Enhancing mechanical and durability properties of recycled aggregate concrete. Constr. Build. Mater. 2018, 158, 228-235. [CrossRef]

14. Lu, J.-X.; Yan, X.; He, P.; Poon, C.S. Sustainable design of pervious concrete using waste glass and recycled concrete aggregate. J. Clean. Prod. 2019, 234, 1102-1112. [CrossRef]

15. Zhao, Z.; Remond, S.; Damidot, D.; Xu, W. Influence of fine recycled concrete aggregates on the properties of mortars. Constr. Build. Mater. 2015, 81, 179-186. [CrossRef]

16. Théréné, F.; Keita, E.; Naël-Redolfi, J.; Boustingorry, P.; Bonafous, L.; Roussel, N. Water absorption of recycled aggregates: Measurements, influence of temperature and practical consequences. Cem. Concr. Res. 2020, 137, 106196. [CrossRef]

17. Kazemian, F.; Rooholamini, H.; Hassani, A. Mechanical and fracture properties of concrete containing treated and untreated recycled concrete aggregates. Constr. Build. Mater. 2019, 209, 690-700. [CrossRef]

18. Abid, S.R.; Nahhab, A.H.; Al-Aayedi, H.K.; Nuhair, A.M. Expansion and strength properties of concrete containing contaminated recycled concrete aggregate. Case Stud. Constr. Mater. 2018, 9, 00201. [CrossRef]

19. Rehder, B.; Banh, K.; Neithalath, N. Fracture behavior of pervious concretes: The effects of pore structure and fibers. Eng. Fract. Mech. 2014, 118, 1-16. [CrossRef]

20. Yahia, A.; Kabagire, K.D. New approach to proportion pervious concrete. Constr. Build. Mater. 2014, 62, 38-46. [CrossRef]

21. Bhutta, M.A.R.; Tsuruta, K.; Mirza, J. Evaluation of high-performance porous concrete properties. Constr. Build. Mater. 2012, 31, 67-73. [CrossRef]

22. Qin, Y. A review on the development of cool pavements to mitigate urban heat island effect. Renew. Sustain. Energy Rev. 2015, 52, 445-459. [CrossRef]

23. Carsana, M.; Tittarelli, F.; Bertolini, L. Use of no-fines concrete as a building material: Strength, durability properties and corrosion protection of embedded steel. Cem. Concr. Res. 2013, 48, 64-73. [CrossRef]

24. Shabalala, A.N.; Ekolu, S.O.; Diop, S.; Solomon, F. Pervious concrete reactive barrier for removal of heavy metals from acid mine drainage-Column study. J. Hazard. Mater. 2017, 323, 641-653. [CrossRef] [PubMed]

25. NRMCA Pervious Concrete Pavement. Available online: http://www.perviouspavement.org/index.html (accessed on 10 August 2020).

26. Tennis, P.D.; Leming, M.L.; Akers, D.J. Pervious Concrete Pavement; Portland Cement Association and National Ready Mixed Concrete Association: Skokie, IL, USA; Silver Spring, MD, USA, 2004.

27. ACI 522R-10 2010. ACI Committee 522 Report on Pervious Concrete; ACI Committee: Farmington Hills, MI, USA, 2010.

28. Ibrahim, H.A.; Goh, Y.; Ng, Z.A.; Yap, S.P.; Mo, K.H.; Yuen, C.W.; AbuTaha, F. Hydraulic and strength characteristics of pervious concrete containing a high volume of construction and demolition waste as aggregates. Constr. Build. Mater. 2020, $253,119251$. [CrossRef]

29. Teixeira, E.; Mateus, R.; Camões, A.; Branco, F. Quality and durability properties and life-cycle assessment of high volume biomass fly ash mortar. Constr. Build. Mater. 2019, 197, 195-207. [CrossRef] 
30. Feiz, R.; Ammenberg, J.; Baas, L.; Eklund, M.; Helgstrand, A.; Marshall, R. Improving the CO2 performance of cement, part I: Utilizing life-cycle assessment and key performance indicators to assess development within the cement industry. J. Clean. Prod. 2015, 98, 272-281. [CrossRef]

31. Celik, K.; Meral, C.; Gursel, A.P.; Mehta, P.K.; Horvath, A.; Monteiro, P.J. Mechanical properties, durability, and life-cycle assessment of self-consolidating concrete mixtures made with blended portland cements containing fly ash and limestone powder. Cem. Concr. Compos. 2015, 56, 59-72. [CrossRef]

32. Chau, C.; Leung, T.; Ng, W. A review on Life Cycle Assessment, Life Cycle Energy Assessment and Life Cycle Carbon Emissions Assessment on buildings. Appl. Energy 2015, 143, 395-413. [CrossRef]

33. Xu, G.; Shi, X. Characteristics and applications of fly ash as a sustainable construction material: A state-of-the-art review. Resour. Conserv. Recycl. 2018, 136, 95-109. [CrossRef]

34. ABNT NBR 16697. Portland Cement-Requirements; Brazilian National Standards Organization: Rio de Janeiro, Brazil, $2018 ;$ p. 12.

35. Andrés, L.M.V.; Scrivener, K.L.; Díaz, A.A.; Hernandez, J.F.M.; Antoni, M.G. Effect of fineness in clinker-calcined clays-limestone cements. Adv. Cem. Res. 2015, 27, 546-556. [CrossRef]

36. ABNT NBR NM 248. Aggregates-Sieve Analysis of Fine and Coarse Aggregates; Brazilian National Standards Organization: Rio de Janeiro, Brazil, 2003; p. 6.

37. ABNT NBR NM 53. Coarse Aggregate-Determination of the Bulk Specific Gravity, Apparent Specific Gravity and Water Absorption; Brazilian National Standards Organization: Rio de Janeiro, Brazil, 2009; p. 8.

38. ABNT NBR NM 45. Aggregates-Determination of the Unit Weight and Air-Void Contents; Brazilian National Standards Organization: Rio de Janeiro, Brazil, 2006; p. 8.

39. ABNT NBR NM 46. Aggregates-Determination of Material Finer than 75 um Sieve by Washing; Brazilian National Standards Organization: Rio de Janeiro, Brazil, 2003; p. 6.

40. ABNT NBR NM 51. Small-Size Coarse Aggregate-Test Method for Resistance to Degradation by Los Angeles Machine; Brazilian National Standards Organization: Rio de Janeiro, Brazil, 2001; p. 6.

41. Barbudo, A.; De Brito, J.; Evangelista, L.; Bravo, M.; Agrela, F. Influence of water-reducing admixtures on the mechanical performance of recycled concrete. J. Clean. Prod. 2013, 59, 93-98. [CrossRef]

42. ABNT NBR 16416. Pervious Concrete Floors-Requirements and Procedures; Brazilian National Standards Organization: Rio de Janeiro, Brazil, 2015; p. 25.

43. Debnath, B.; Sarkar, P.P. Characterization of pervious concrete using over burnt brick as coarse aggregate. Constr. Build. Mater. 2020, 242, 118154. [CrossRef]

44. Schaefer, V.R.; Wang, K.; Suleiman, M.T.; Kavern, J. Mix design development for pervious concrete in cold weather climates. In Final Report 2006; Iowa Department of Transportation: Ames, IA, USA, 2006; p. 83.

45. ASTM. ASTM C860-15. Standard Test Method for Determining the Consistency of Refractory Castable Using the Ball-In-Hand Test; ASTM International: West Conshohocken, PA, USA, 2019; p. 4.

46. ABNT NBR 9833. Fresh Concrete-Determination of Specific Gravity, Yield and Air Content by the Gravimetric Method; Brazilian National Standards Organization: Rio de Janeiro, Brazil, 2008; p. 7.

47. ASTM. ASTM C1754. Standard Test Method for Density and Void Content of Hardened Pervious Concrete; ASTM International: West Conshohocken, PA, USA, 2012; p. 3.

48. ABNT NBR 5739. Concrete-Compressive strength Test of Cylindrical Specimens; Brazilian National Standards Organization: Rio de Janeiro, Brazil, 2018; p. 9.

49. ABNT NBR 9781. Concrete Paving Pieces—Specification and Test Methods; Brazilian National Standards Organization: Rio de Janeiro, Brazil, 2013; p. 21.

50. ABNT NBR 12142. Concrete-Determination of Tension Strength in Flexure of Prismatic Specimens; Brazilian National Standards Organization: Rio de Janeiro, Brazil, 2010; p. 5.

51. ASTM. ASTM C597. Standard Test Method for Pulse Velocity through Concrete; ASTM International: West Conshohocken, PA, USA, 2016; p. 4.

52. Vieira, G.L.; Schiavon, J.Z.; Borges, P.M.; Da Silva, S.R.; Andrade, J.J.D.O. influence of recycled aggregate replacement and fly ash content in performance of pervious concrete mixtures. J. Clean. Prod. 2020, 271, 122665. [CrossRef]

53. ASTM. ASTM C1688. Standard Test Method for Density and Void Content of Freshly Mixed Pervious Concrete; ASTM International: West Conshohocken, PA, USA, 2014; p. 4.

54. ASTM. ASTM C39: Standard Test Method for Compressive Strength of Cylindrical Concrete Specimens; ASTM International: West Conshohocken, PA, USA, 2020; p. 8.

55. Navidi, W. Statistics for Engineers and Scientists, 4th ed.; McGraw-Hill Education: New York, NY, USA, 2015; ISBN 978-0-07-340133-1.

56. ASTM. ASTM C1161: Standard Test Method for Flexural Strength of Advanced Ceramics at Ambient Temperature; ASTM International: West Conshohocken, PA, USA, 2018.

57. Goede, W.G. Pervious Concrete: Investigation into Structural Performance and Evaluation of the Applicability of Existing Thickness Design Methods; Washington State University: Washington, DC, USA, 2009.

58. ABNT NBR 13292. Soil-Determination of the coefficient of permeability from granular soils at constant head; Brazilian National Standards Organization: Rio de Janeiro, Brazil, 2021; p. 13. 
59. ASTM. ASTM C1701/C1701M: Standard Test Method for Infiltration Rate of in Place Pervious Concrete; ASTM Internacional: West Conshohocken, PA, USA, 2017; p. 3.

60. NRMCA. Freeze-Thaw Resistance of Pervious Concrete; NRMCA: Alexandria, VA, USA, 2004.

61. Mateus, R.; Bragança, L. Tecnologias Construtivas Para a Sustentabilidade da Construção (in English Building Technologies for Sustainable Construction); Edições Ecopy: Porto, Portugal, 2010; ISBN 9789899519411.

62. Mateus, R.; Neiva, S.D.O.; Bragança, L.; Mendonça, P.; Macieira, M. Sustainability assessment of an innovative lightweight building technology for partition walls-Comparison with conventional technologies. Build. Environ. 2013, 67, 147-159. [CrossRef]

63. Teixeira, E.R.; Mateus, R.; Camões, A.F.; Bragança, L.; Branco, F.G. Comparative environmental life-cycle analysis of concretes using biomass and coal fly ashes as partial cement replacement material. J. Clean. Prod. 2016, 112, 2221-2230. [CrossRef]

64. Li, X.; Zhu, Y.; Zhang, Z. An LCA-based environmental impact assessment model for construction processes. Build. Environ. 2010, 45, 766-775. [CrossRef]

65. EPD. Votorantim EPD—Environmental Product Declaration; EPD: São Paulo, Brazil, 2020; p. 14.

66. ISO. ISO 14040 Environmental Management_Life Cycle Assessment_Principles and Framework; ISO: Geneva, Switzerland, $2006 ;$ p. 20.

67. Frischknecht, R.; Jungbluth, N.; Althaus, H.; Bauer, C.; Doka, G.; Dones, R.; Hischier, R.; Hellweg, S.; Köllner, T.; Loerincik, Y.; et al. Implementation of Life Cycle Impact Assessment Methods; Ecoinvent: Zurich, Switzerland, 2010.

68. CEN EN 15804. Sustainability of Construction Works—Environmental Product Declarations—Core Rules for the Product Category of Construction Products; CEN: Brussels, Belgium, 2012.

69. Ahmaruzzaman, M. A review on the utilization of fly ash. Prog. Energy Combust. Sci. 2010, 36, 327-363. [CrossRef]

70. Yang, X.; Liu, J.; Li, H.; Ren, Q. Performance and ITZ of pervious concrete modified by vinyl acetate and ethylene copolymer dispersible powder. Constr. Build. Mater. 2020, 235, 117532. [CrossRef]

71. Singh, N.; Kumar, P.; Goyal, P. Reviewing the behaviour of high volume fly ash based self compacting concrete. J. Build. Eng. 2019, 26, 100882. [CrossRef]

72. Wang, R.; Yu, N.; Li, Y. Methods for improving the microstructure of recycled concrete aggregate: A review. Constr. Build. Mater. 2020, 242, 118164. [CrossRef]

73. Mehta, P.K.; Monteiro, P.J.M. Concreto: Microestrutura, Propriedades e Materiais; Ibracon, 2a Edição: São Paulo, Brazil, $2014 ;$ p. 751.

74. Kim, Y.; Hanif, A.; Usman, M.; Park, W. Influence of bonded mortar of recycled concrete aggregates on interfacial characteristicsPorosity assessment based on pore segmentation from backscattered electron image analysis. Constr. Build. Mater. 2019, 212, 149-163. [CrossRef]

75. Silva, R.V.; De Brito, J.; Dhir, R.K. Properties and composition of recycled aggregates from construction and demolition waste suitable for concrete production. Constr. Build. Mater. 2014, 65, 201-217. [CrossRef]

76. Poon, C.S.; Chan, D. Paving blocks made with recycled concrete aggregate and crushed clay brick. Constr. Build. Mater. 2006, 20, 569-577. [CrossRef]

77. Cook, R.A.; Goodspeed, C.; Vanicar, S. Evaluation of "High-Performance Concrete Defined For Highway Structures."; Federal Highway Administration: Washington, DC, USA, 1998.

78. Chandrappa, A.K.; Biligiri, K.P. Influence of mix parameters on pore properties and modulus of pervious concrete: An application of ultrasonic pulse velocity. Mater. Struct. 2016, 49, 5255-5271. [CrossRef]

79. Zhang, C.-Y.; Han, R.; Yu, B.; Wei, Y.-M. Accounting process-related CO2 emissions from global cement production under Shared Socioeconomic Pathways. J. Clean. Prod. 2018, 184, 451-465. [CrossRef]

80. Cao, Z.; Shen, L.; Zhao, J.; Liu, L.; Zhong, S.; Yang, Y. Modeling the dynamic mechanism between cement CO2 emissions and clinker quality to realize low-carbon cement. Resour. Conserv. Recycl. 2016, 113, 116-126. [CrossRef]

81. Zulcão, R.; Calmon, J.L.; Rebello, T.A.; Vieira, D.R. Life cycle assessment of the ornamental stone processing waste use in cement-based building materials. Constr. Build. Mater. 2020, 257, 119523. [CrossRef]

82. Heede, P.V.D.; De Belie, N. Environmental impact and life cycle assessment (LCA) of traditional and 'green' concretes: Literature review and theoretical calculations. Cem. Concr. Compos. 2012, 34, 431-442. [CrossRef] 